\title{
Delimitation of cryptic species drastically reduces the geographical ranges of marine interstitial ghost-worms (Stygocapitella; Annelida, Sedentaria)
}

\author{
José Cerca $^{\mathrm{a}, *}$, Christian Meyer ${ }^{\mathrm{b}}$, Günter Purschke ${ }^{\mathrm{b}}$, Torsten H. Struck ${ }^{\mathrm{a}}$ \\ ${ }^{a}$ Frontiers of Evolutionary Zoology Research Group, Natural History Museum, University of Oslo, 0562 Oslo, Norway \\ ${ }^{\mathrm{b}}$ Zoology and Developmental Biology, Department of Biology and Chemistry, University of Osnabrück, Barbarastr. 11, 49069 Osnabrück, Germany
}

\section{A R T I C L E I N F O}

\section{Keywords:}

Sibling species

Biogeography

Marine connectivity

Phylogenetics

Distribution range

Dispersal

\begin{abstract}
A B S T R A C T
The recognition of cryptic species concealed in traditionally established species may reveal new biogeographical patterns and alter the understanding of how biodiversity is geographically distributed. This is particularly relevant for marine ecosystems where the incidence of cryptic species is high and where species distribution data are often challenging to collect and interpret. Here, we studied specimens of the 'cosmopolitan' interstitial meiofaunal annelid Stygocapitella subterranea Knöllner, 1934 (Parergodrilidae, Orbiniida), obtaining data from four coastlines in the Northern hemisphere. Using phylogenetic tools and several species-delimitation methods (haplotype networks, GMYC, bPTP, maximum likelihood, posterior probability and morphology) we describe eight new Stygocapitella species. With one exception, all species are present along a single coastline, ultimately challenging the idea that Stygocapitella subterranea has a cosmopolitan distribution. We found evidence for several oceanic transitions having occurred in the past as well as a recent translocation, potentially due to human activity. No diagnostic characters were found, and qualitative and quantitative morphological data do not allow an unequivocal differentiation of the identified cryptic species. This suggests that (i) neither traditional diagnostic features nor quantitative morphology suffice to recognise species boundaries in cryptic species complexes, such as the Stygocapitella species complex; and that (ii) the recognition and description of cryptic species is of seminal importance for biodiversity assessments, biogeography and evolutionary biology.
\end{abstract}

\section{Introduction}

Species distribution data provide a valuable proxy to understand patterns of biodiversity occurrence across the globe, the influence of past geological events on taxa, but also of human impact on biological communities (Holt et al., 2013). However, quantifying biodiversity and species distributions can be challenging (Knowlton, 2000, 1993; Leray and Knowlton, 2016). For instance, in marine environments, sampling of biodiversity often requires expensive equipment and big teams. Boundaries and biogeographic barriers are often hard to determine, and the patchiness of marine populations combined with the wide area occupied by oceans contributes to difficult sampling and collection. Species delimitation and identification are often compromised because organisms can be deformed following their collection and extraction from the water, due to preservation practices, or because they require sound taxonomic expertise, including adult features and unequivocal diagnostic characters (Cerca et al., 2018; Hellberg, 2009; Knowlton, 1993; Sterrer, 1973). As a result, our understanding of evolutionary and ecological processes as well as biogeographic patterns in the sea is severely diminished (Hellberg, 2009; Johannesson, 1988; Knowlton, 1993).

Cryptic species add another layer of complexity to biodiversity assessments (Knowlton, 1993; Pante et al., 2015) and to the determination of species' distributions (Cerca et al., 2018; Knowlton, 2000, 1993). The debate whether cryptic species result from natural phenomena or taxonomic artefacts has recently sparked attention (Fišer et al., 2018; Korshunova et al., 2019, 2017; Pante et al., 2015). A recent view has argued that the uncertainty in this debate essentially derives from placing the focus on the taxonomic history of the species complex, rather than focusing on the accumulation of morphological disparity through time or lack thereof (Struck et al., 2018a, 2018b; Struck and Cerca, 2019). To distinguish between these two aspects, it was suggested that species should be first investigated and delimited using all available data (e.g. morphological, ecological and behavioural data). The assignment of the 'cryptic' status, should then follow, but only after and independent from the species delimitation process. In this step, one should quantify morphological disparity. The status of 'cryptic species' should only be attributed if the species under consideration are

\footnotetext{
* Corresponding author.

E-mail address: jose.cerca@gmail.com (J. Cerca).
} 
morphologically more similar to each other than expected, given the time since species divergence. The comparison with closely related outgroups, displaying clear morphological differences is beneficial to this procedure as it allows gauging the degree of morphological disparity in closely related lineages (for a more detailed discussion of the problems in assigning cryptic species please see (Struck et al., 2018a, 2018b; Struck and Cerca, 2019)). These guidelines allow distinguishing species, which are morphologically decelerated (i.e., cryptic species), from cryptic species complexes resulting from taxonomic artefacts such as erroneous descriptions, or from poorly sampled and preserved data. Importantly, distinguishing between both opens the possibility to study processes leading to the deceleration of morphological evolution and its underlying causes.

One particularly interesting group of marine organisms with a high incidence of cryptic species and little-known distribution is the interstitial fauna of coastal sediments (Cerca et al., 2018; Giere, 2009; Westheide, 1977). These habitats harbour a rich biodiversity, with organisms being typically found in the space between sand grains in beaches along continental coastlines (Giere, 2009). The overall convergence of body plan, and the suggested occurrence of high rates of morphological stasis (i.e. retention of the same ancestral character state over an extended period) results in high incidences of cryptic species in this group (Cerca et al., 2018; Jörger and Schrödl, 2013; Westheide, 1987). Taken together, these have been suggested to confound the study of meiofauna species' distribution (Cerca et al., 2018; Leasi and Norenburg, 2016). For instance, Stygocapitella subterranea was first described from the Baltic coastline of Germany (Knöllner, 1934). It was later found in numerous places across European coastlines including the Mediterranean and Black Sea, Northern America, as well as New Zealand and Australia (Purschke et al., 2019; Westheide, 2008, 1990), leading to the interpretation that $S$. subterranea is a cosmopolitan-distributed species (Riser, 1984). Recent investigations using a combination of genetic and morphological data from the Southern hemisphere led to the description of two new Stygocapitella species, S. minuta Struck et al., 2017 and S. australis Struck et al., 2017 (Fig. 1). RAPD-PCR data suggested that three different lineages of $S$. subterranea from different coastlines of the Northern hemisphere are genetically distinct (Schmidt

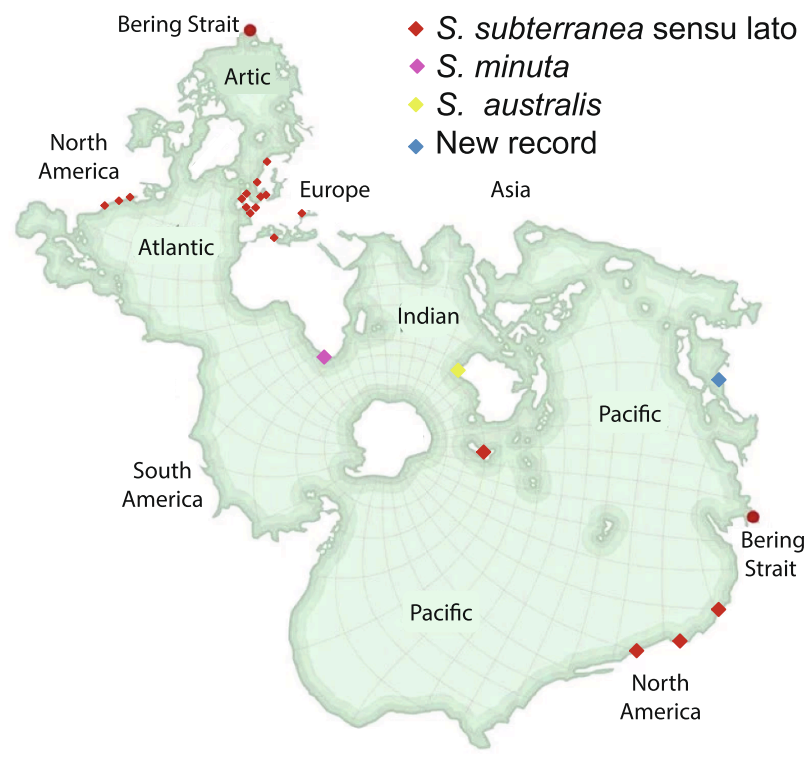

Fig. 1. Stygocapitella records considered to date. Stygocapitella subterranea (red diamond; sensu lato) has been recognised as a cosmopolitan species, $S$. minuta (purple diamond) is found in South Africa and $S$. australis (yellow diamond) in Australia. As part of this work we report Stygocapitella occurring in Volchanets (Far-east Russia; blue diamond). (For interpretation of the references to color in this figure legend, the reader is referred to the web version of this article.) and Westheide, 2000), with specimens from Europe and North America (Atlantic) grouping together, and specimens from the Pacific being distantly related to this group (Schmidt and Westheide, 2000). Hence, it is uncertain if $S$. subterranea has a distribution with population structure, or whether these are potentially different species.

The aim of this study is to do a phylogeographic reconstruction of lineages belonging to Stygocapitella, including data from S. subterranea specimens occurring along the Northern European, East-Northern American, West-Northern American, and Far-Eastern Russian coastlines. We complement this with data from the $S$. australis and S. minuta, which respectively occur in the Australian and South African coastlines, to determine genetic and morphological differences between lineages, and whether these are different species. We (i) delimitate species using phylogenetic tools, species delimitation algorithms and haplotype networks and follow the phylogenetic species concept; and (ii) assess morphological similarity between Stygocapitella species. We find evidence for several morphologically similar or identical species (i.e. cryptic species), which differ only in their geographic distribution at different coastlines. In addition, we find evidence for the occurrence of several oceanic translocations, including one potentially due to human activity. We discuss the importance of recognising and delimiting cryptic species, as well as the role of morphological-oriented practices in cryptic species complexes.

\section{Methods}

\subsection{Field work and species identification}

Stygocapitella spp. are interstitial annelids generally found around and above the high-water line of stable, sheltered gravel or sandy beaches (Purschke et al., 2019). To collect specimens, we selected beaches based on old records or by assessment of the area using google maps (Supplementary Table 1). At each site, we drew a transect roughly perpendicular to the coastline from the high-water line to the foot of the dune. After drawing the transect, we dug a hole every meter and collected sediment samples in plastic bags (volume of $375 \mathrm{~cm}^{3}$ ) at intervals of $15 \mathrm{~cm}(0-15 ; 15-30 ; \ldots)$ until approximately $60-75 \mathrm{~cm}$ depth or till the ground water. Interstitial invertebrate communities were then extracted using the $\mathrm{MgCl}_{2}$ method and sorted under a dissecting microscope (Westheide and Purschke, 1988). After identification, we preserved specimens for molecular biology and for morphological analyses, either by transferring these to a solution of $\sim 70 \%$ ethanol or to a fixative containing picric acid, formaldehyde and glutaraldehyde adjusted with sucrose to sea water osmolality (Sucrose-picric-acidparafolmaldehyde-glutaraldehyde; SPAFG) following Westheide and Purschke (1988), respectively. Lists of individuals used for molecular and for quantitative morphological analyses are provided in Supplementary Tables 2 and 3, respectively.

\subsection{DNA extraction and amplification}

DNA extractions were carried out using either phenol-chloroform or the E.Z.N.A Tissue DNA Kit (Omega Bio-Tek). The nuclear markers 18S (complete) and ITS1 and the mitochondrial CO1 were amplified using the QIAGEN $^{\circledR}$ Multiplex PCR Kit (Qiagen, Hilden, Germany) in a $10 \mu \mathrm{l}$ reaction-mix containing $5 \mu \mathrm{l}$ of multiplex mix, $1 \mu \mathrm{l}$ Q-solution, $0.8 \mu \mathrm{l}$ $10 \mu \mathrm{M}$ of both forward and reverse primer, $1 \mu \mathrm{l}$ genomic DNA and $1.4 \mu \mathrm{l}$ deionized water. The mitochondrial gene $16 \mathrm{~S}$ was amplified using a $25 \mu \mathrm{l}$ reaction-mix, which included $15.2 \mu \mathrm{l}$ of $\mathrm{H}_{2} \mathrm{O}, 2.5 \mu \mathrm{l}$ of 10X PCR Buffer I (with $\mathrm{MgCl}_{2}$ added; Applied Biosystems), $2.5 \mu \mathrm{l}$ of BSA, $0.5 \mu \mathrm{l}$ of $10 \mathrm{mM}$ dNTPs, $1.6 \mu \mathrm{l} 10 \mu \mathrm{M}$ of both forward and reverse primer and $0.13 \mu \mathrm{l}$ of amplitaq gold (Applied Biosystems). For COI, we used the primers LCO1490-JJ (CHACWAAYCATAAAGATARYGG) and HCO2198-JJ (AWACTTCVGGRTGVCCAAARAATCA; both Astrin and Stüben, 2008), for $18 \mathrm{~S}$ 18e (CTGGTTGATCCTGCCAGT, Hillis and Dixon, 1991) and 18R1779 (TGTTACCGACTTTTACTTCCTCTA; (Struck 
et al., 2002), and for ITS1 species-specific primers Stygo_ITS1_F (TGT TGATTACGTCCCTGCCC; this study) and Stygo_ITS1_R (GTCAACCGAC CCTGAGACAG; this study), and for 16S 16SarL (CGCCTGTTTATCAAA AACAT; Palumbi et al., 1991) and 16S_AN-R (GCTTACGCCGGTCTGA ACTCAG; (Zanol et al., 2010). Exceptionally, polyLCO (GAYTATWTTCAACAAATCATAAAGATATTGG) and polyHCO (TAMACTTCWGGGTGACCAAARAATC; both Lobo et al., 2016) were used for individuals from the Atlantic-American sites as they yielded better results. PCR conditions for ITS1 included: an initial denaturation: $15^{\prime} 95^{\circ} \mathrm{C}$; $40 \mathrm{cy}-$ cles: $30^{\prime \prime} 95^{\circ} \mathrm{C}, 30^{\prime \prime} 66^{\circ} \mathrm{C}, 1^{\prime} 72^{\circ} \mathrm{C}$; and a final elongation: $20^{\prime} 72^{\circ} \mathrm{C}$; for $16 \mathrm{~S}$ we included a touchdown procedure: an initial denaturation: $15^{\prime}$ $95^{\circ} \mathrm{C}$; 40 cycles: $30^{\prime \prime} 94^{\circ} \mathrm{C}, 30^{\prime \prime} 51^{\circ} \mathrm{C}$ (touchdown: $-0.2^{\circ} \mathrm{C}$ per cycle), $2^{\prime}$ $65^{\circ} \mathrm{C}$; final elongation: $7^{\prime} 65^{\circ} \mathrm{C}$; for $18 \mathrm{~S}$ a touchdown/touch-up: initial denaturation: $15^{\prime} 95^{\circ} \mathrm{C}$; 15 cycles: $35^{\prime \prime} 94^{\circ} \mathrm{C}, 90^{\prime \prime} 55^{\circ} \mathrm{C}$ (touchdown: $-1{ }^{\circ} \mathrm{C}$ per cycle), $2.5^{\prime} 72^{\circ} \mathrm{C}$; 25 cycles: $35^{\prime \prime} 94^{\circ} \mathrm{C}, 90^{\prime \prime} 50^{\circ} \mathrm{C}, 2.5^{\prime} 72^{\circ} \mathrm{C}$; final elongation: $10^{\prime} 72^{\circ} \mathrm{C}$. Finally, for COI: initial denaturation of: $15^{\prime}$ $95^{\circ} \mathrm{C}$; 15 cycles: $35^{\prime \prime} 94^{\circ} \mathrm{C}, 90^{\prime \prime} 55^{\circ} \mathrm{C}$ (touchdown: $-1^{\circ} \mathrm{C}$ per cycle), $1.5^{\prime}$ $72{ }^{\circ} \mathrm{C}$; 25 cycles: $35^{\prime \prime} 94^{\circ} \mathrm{C}, 90^{\prime \prime} 50^{\circ} \mathrm{C}, 1.5^{\prime} 72^{\circ} \mathrm{C}$; final elongation: $10^{\prime}$ $72^{\circ} \mathrm{C}$. PCR fragments were purified using a 10 times dilution of a phosphatase-exonuclease mix and Sanger-sequenced by MacrogenEurope. Considering the length of the $18 \mathrm{~S}$ fragment, four additional sequencing primers were included as sequencing primers: $18 \mathrm{r}$ (CTCTA ATTTTTTCAAAGTAAAC), 18L (AGCTCTCAATCTGTCAATCCT; both Hillis and Dixon, 1991), 18F997 (TTCGAAGACGATCAGATACCG; Struck et al., 2002) and 18SF3_Stygo (CCTCGGGATTGGAATGAGTAC; Struck et al., 2017). After sequencing, we assembled sequences using Geneious (v6.8.1). The ends of sequences were automatically trimmed to remove the primers, visually checked, and manually trimmed to account for low quality ends. Finally, consensus sequences were blasted using NCBI database to exclude contamination.

\subsection{Phylogenetic and molecular clock analyses}

In total, we included sequence information for 353 specimens belonging to 33 sites in the Northern Hemisphere, as well as data from other Stygocapitella species of the Southern hemisphere and species of Orbiniidae, the sister group of Parergodrilidae (Supplementary Tables 1 and 2; Supplementary Fig. 1). We aligned COI, 16S and $18 \mathrm{~S}$ sequences using MAFFT v7.310, with a maximum of 1,000 iterations and using the local pair alignment algorithm (mafft -maxiterate 1000 -localpair -reorder input.fa $>$ output.fa) (Katoh and Standley, 2013). For ITS1 sequences, we adopted a different strategy as these sequences ranged from 750 to $1,600 \mathrm{bp}$, resulting from tandem repeats. As we were not able to align these initially, we removed sequences longer than $1,100 \mathrm{bp}$. This allowed aligning ITS1 using the global pair alignment algorithm (-globalpair), which accounts for gap-rich sequences. After aligning sequences and removing about $5 \%$ of the sequences due to long missing-ends, both ends were trimmed until the first position without missing data. To inspect congruence of the datasets (i.e. if separate genes cluster individuals and species similarly), we performed separate maximum likelihood analyses of each gene (Supplementary Figs. 2-5). Single gene analyses were conducted using IQ-tree v1.6.7 (Chernomor et al., 2016; Nguyen et al., 2015) with an automatic determination of the best substitution model for each gene, 300 initial parsimony trees, 15 best trees retained during search and 1,000 ultrafrast bootstrap replicates (iqtree -s input.fa -nt AUTO -ninit 300 -nbest 15 -bb 1000 -wbtl) (Hoang et al., 2017). Finally, we concatenated the four genes into a single multi-gene alignment using FASconCAT v1.1 (Kück and Meusemann, 2010), and did a partitioned Maximum Likelihood (ML) analysis using IQ-tree as described for the single-gene analyses (Fig. 2).

Bayesian inference (BI) was applied using BEAST v2.4.7 (Bouckaert et al., 2014). Before running any analyses we determined substitution models that best fit the data using IQ-tree's ModelFinder (Kalyaanamoorthy et al., 2017). After performing several runs using combinations of different prior models and genes, we opted to remove $16 \mathrm{~S}$ and ITS1 from further analyses because chain convergence could not be achieved. After this, we ran several analyses, some including missing data for either COI or $18 \mathrm{~S}$ or without missing data (i.e. including only specimens for which both genes were present). Given the substantial differences in chain convergence we opted for the latter strategy. For the final analysis, the trees of COI and $18 \mathrm{~S}$ were linked and the best fitting-models were TNe + I (Model TN93; Frequencies: All equal) for $18 \mathrm{~S}$ and TIM $+\mathrm{F}+\mathrm{I}+\mathrm{G} 4(\mathrm{~F}=$ Empirical base frequencies; I = Invariable sites; $\mathrm{G}=$ Gamma model) for COI. To apply the TIM model in BEAST we selected the GTR model, with all frequencies to be estimated, apart for AG and CT, and 4 gamma categories. A relaxed, log-normal clock was applied with a substitution rate of 0.0001425 for 18 S (Struck et al., 2017) and 0.0176 for COI (Lehmacher et al., 2016). We selected a birth-death model and a MCMC run for 100,000,000 generations sampling every 100,000 generation. Convergence was confirmed using Tracer v1.6 (Rambaut et al., 2007). A Maximum Credibility Consensus Tree was obtained using TreeAnnotator, with a 10\% burn-in (Bouckaert et al., 2014).

\subsection{Haplotype networks and species delineation}

Haplotype networks of each separate genetic marker were build using TCS (Clement et al., 2000), with a connection limit of 95\%. Gaps were considered as a fifth state. Graphical representation was done with tcsBU (Múrias Dos Santos et al., 2015), and then redesigned using Adobe Illustrator. We have adopted several species delineation approaches as suggested as best practice (Carstens et al., 2013). These included a GMYC model at https://species.h-its.org/gmyc/ (Fujisawa and Barraclough, 2013), a bPTP model at https://species.h-its.org/ptp/ (Zhang et al., 2013), 16S- and COI-based 95\% connection limits using TCS (Clement et al., 2000), a posterior probability cut-off of 0.9 based on the generated Bayesian tree and a bootstrap cut-off of $95 \%$ based on the ML tree. The GMYC analysis was performed based on the obtained Bayesian tree (based on $18 \mathrm{~S}$ and COI) and the bPTP on the obtained ML tree (concatenated, partitioned dataset including 16S, 18S, COI and ITS1). In addition to the genetic data, we did a 'morphological species delineation' with the aim of obtaining diagnostic features, based on the presence of certain chaetal types on the $1^{\text {st }}, 2^{\text {nd }}, 3^{\text {rd }}$ and consecutive chaetigers - the only variable morphological features we were able to obtain in our data.

\subsection{Morphological data analysis}

We investigated morphological disparity by using morphological measurement data obtained via light microscopy. To do so, we photographed single Stygocapitella specimens at $10 \mathrm{X}$ amplification. Because this resulted in multiple photos, we stitched photos together to form a whole-organism photograph using Photoshop. We then used ImageJ to measure body length and width, prostomium length and width, and pygidium length and width. In total, we obtained measures from 133 Stygocapitella specimens (Supplementary Table 3). Measurements were analysed using general linear models (GLM), Least Square Means analyses (Lenth, 2013) and principal component analyses. For each measurement, we fit a GLM model, using "measurement" as the dependent variable and "Stygocapitella lineage" as the independent variable. Because GLM models do not allow assessing differences between factorial variables (in this case "Stygocapitella lineage"), we fit a Least Square Means analysis to each model. This analysis provides pairwise statistical comparisons between factorial variables (i.e. "Stygocapitella lineage"), providing $p$-value evaluations between factors. Significance thresholds were then obtained with a Likelihood ratio test using the function drop1 as part of R's stats-package (R Core Team, 2013). After this, we conducted principal component analyses using all six measurements and the function prcomp included in R's stats-package (R Core Team, 2013). Plotting of results was done using the ggplot2 package (Wickham, 2016) and the Hmisc package (Harrell Jr and Many Others, 2019).

In addition to morphological measurements, we looked for presence 


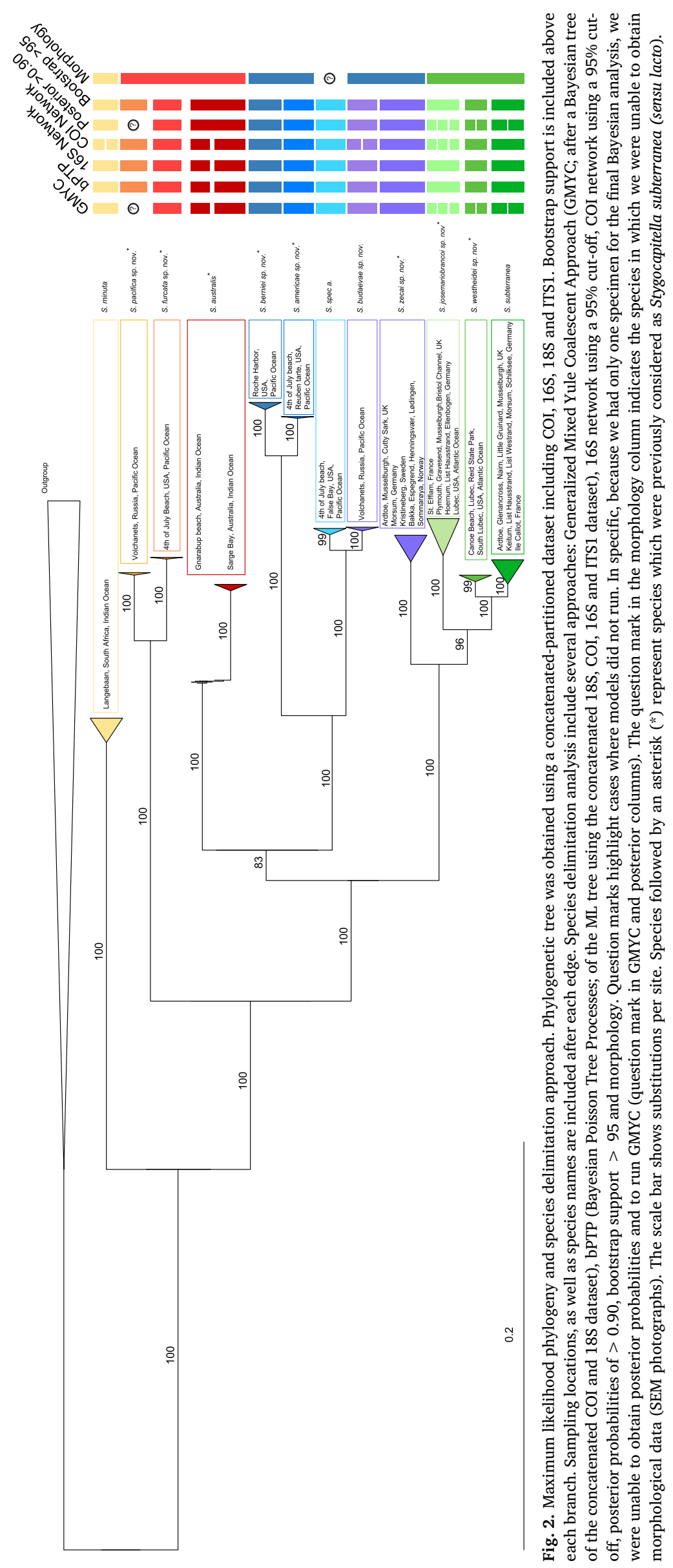


of chaetal differences using scanning electron microscopy (SEM). Specimens selected for SEM were rinsed in phosphate buffer and then treated with a buffered $1 \% \mathrm{OsO}_{4}$ solution for one hour at ambient temperature. This was followed by dehydration in a graded ethanol series starting in $30 \%$ ethanol and finishing in $100 \%$ ethanol. Dehydrated specimens were then critically-point-dried with $\mathrm{CO}_{2}$, mounted on aluminium stubs and sputter-coated with platinum. SEM photographs from (i) the whole body, (ii) segments with chaetae (chaetiger), and (iii) the type and number of chaetae in each chaetiger were obtained using a Zeiss Auriga field emission SEM.

\section{Results}

\subsection{Phylogenetic analyses}

The dataset of 353 specimens comprised 332 16S, 273 COI, $12518 \mathrm{~S}$ and 177 ITS1 sequences. Partitioned ML (Fig. 2) and BI (Fig. 3) of the concatenated data generally resulted in the same topology. Monophyly of both $S$. minuta and $S$. australis is supported by bootstrap support values (BS) of 100 and posterior probabilities (PP) of 1 . The species $S$. subterranea sensu lato from the Northern hemisphere was not recovered as monophyletic and is separated into eight lineages $(B S=99-100 \&$

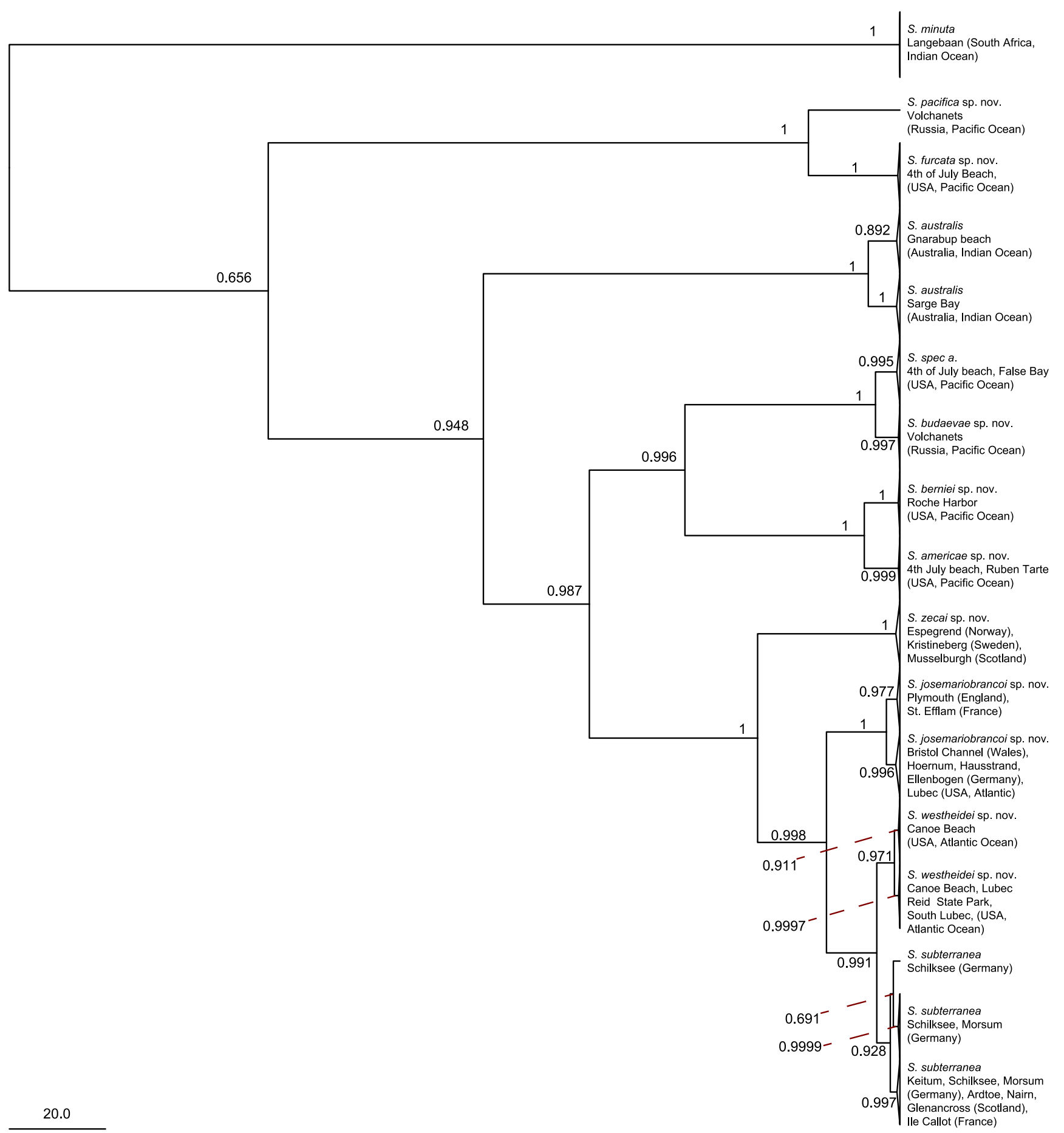

Fig. 3. Bayesian phylogenetic tree based on concatenated $18 \mathrm{~S}$ and COI. Posterior probability is displayed at each branch. Species names and sampling locations are displayed on the species edges. 
$\mathrm{PP}=0.928-1$; Fig. 2). Specimens from Volchanets (Russia; new record in Fig. 1) split into two separate lineages ( $\mathrm{BS}=100 \& \mathrm{PP}=0.997$; one lineage was only represented by one specimen in the BI). Single-gene ML phylogenies retrieved the same lineages as the concatenated datasets, demonstrating congruence between the genes in the dataset (Supplementary Figs. 2-5). The only exception was the highly conserved $18 \mathrm{~S}$ gene that did not unambiguously distinguish the most recent divergences between closely related species (Supplementary Fig. 3). Eight of the lineages in the tree are formally described as new species below, following species delimitation analyses (see below), and for the sake of clarity we use their new species names (S. pacifica sp. nov., $S$. furcata sp. nov., $S$. berniei sp. nov., $S$. americae sp. nov., $S$. budaevae sp. nov., $S$. zecai sp. nov., $S$. josemariobrancoi sp. nov., and $S$. westheidei sp. nov.) in the following sections, as well as in Figs. 2 and 3. Stygocapitella westheidei sp. nov. is sister to the amended $S$. subterranea sensu stricto, and $S$. josemariobrancoi sp. nov. is sister to these two (BB $=100$ and 96 $\& \mathrm{PP}=0.991$ and 0.998 , respectively). These three species are sister to Stygocapitella zecai sp. nov., and together they form the North Atlantic clade $(\mathrm{BB}=100 \& \mathrm{PP}=1)$.

Stygocapitella budaevae sp. nov. is sister to a species which remains undescribed due to the lack of type material and to which we will refer as undescribed species A (BS $=100 \& \mathrm{PP}=1$ ), Stygocapitella berniei sp. nov. is sister to $S$. americae sp. nov. (BS $=100 \& 1)$. Stygocapitella berniei sp. nov., $S$. americae sp. nov, $S$. budaevae sp. nov. and Spec. A form a clade (BS $=100 \&$ 0.987), which is sister to $S$. australis in the ML analysis (BS $=83$, Fig. 2), yet it is sister to the Northern Atlantic clade in the $\mathrm{BI}$ analysis ( $\mathrm{PP}=0.987$, Fig. 3 ). In both analyses all species so far mentioned form a monophyletic group (BS $=100 \& \mathrm{PP}=0.948)$. Stygocapitella pacifica sp. nov. is sister to $S$. furcata sp. nov. (BS $=100 \&$ $\mathrm{PP}=1$ ), together comprising a clade, which is sister to all aforementioned species. All these species form a monophyletic clade, which is sister to $S$. minuta, which is the first to branch off in the Stygocapitella radiation $(\mathrm{BS}=100 \& \mathrm{PP}=0.656)$.

\subsection{Network analyses}

We retrieved haplotype-networks of COI, 16S and ITS1 focusing on the Northern Atlantic, where we did the majority of the sampling efforts (29 sites; Fig. 4), and for all locations (35 sites; Supplementary Fig. 6). Haplotype networks are congruent with phylogenetic results recognizing twelve separate lineages. S. australis displays two unconnected haplotypes, separating specimens geographically. For $S$. zecai sp. nov., the $16 \mathrm{~S}$ haplotype network is divided into two dominant haplotypes which are mostly represented in Scandinavia and Scotland and separated by only one substitution. One of the haplotypes is also present in the North Sea and in Eastern England (Fig. 4). For COI, we were unable to obtain as many sequences as for $16 \mathrm{~S}$, yet we observe a network comprising five haplotypes, with six substitution differences between the two most distant haplotypes. For ITS1, specimens in different areas have distinct haplotypes. Individuals from Scandinavian regions are separated by up to 25 substitution differences. In $S$. josemariobrancoi sp. nov. one ITS1, two $16 \mathrm{~S}$ and three COI haplotype networks are unconnected at $95 \%$ thresholds. Differences in COI and $16 \mathrm{~S}$ are probably due to differences in variability in two genetic markers. For ITS1, the most common haplotype is present in Germany (North Sea), Scotland and France. Specimens from West England have multiple haplotypes, separated between a single substitution up to 31 substitutions. Haplotypes found in East England are subdivided into three closely-related haplotypes, which are 11 substitutions away from the dominant haplotype, and by three specimens which are one and three substitutions away from the dominant haplotype. The two specimens from the USA are nested between the two most common haplotypes. For 16S, one of the two haplotype networks displays a major haplotype present in France, Eastern England and Scotland. The second biggest haplotype in this network is six substitutions away from the major haplotype and only occurs in Western England. The second haplotype network occurs in France, Germany (North Sea), the USA and Western England and has two major haplotypes, which are only separated by a single substitution. Rarer haplotypes occur mostly in Germany (North Sea), being up to eight substitutions different from one of the major haplotypes. In COI, one of the three networks is represented by a single specimen from Bristol Channel. Another is comprised by a dominant haplotype, which is present in Germany (North Sea), France, USA and Western England, and by several haplotypes separated by only one or two substitutions. The third and remaining COI network is comprised by two dominant haplotypes, one occurring in Western England and the other occurring in Eastern England, France and Scotland. This haplotype network is congruent between COI and 16S. 16S and COI retrieve similar networks for $S$. subterranea, revealing a dominant haplotype occurring in Germany (North Sea), Scotland, and France as well as in COI in Germany (Baltic Sea) and Eastern England (Fig. 4). In both genes, $S$. subterranea has haplotypes separated by $5-19$ substitutions from the dominant haplotype, which occurs in Germany (Baltic and North Sea), Scotland and France. For ITS1 in S. subterranea, we were unable to amplify this marker in multiple specimens (Supplementary Table 2). However, 17 substitutions separate the two most distant haplotypes, which occur in Germany (North Sea), and another in Germany (Baltic Sea) and France. In S. westheidei sp. nov., COI and 16S present a very distinct haplotype structure. In $16 \mathrm{~S}$ a single haplotype is present at all sites from the USA (circa $400 \mathrm{~km}$ ) while, on the other hand, COI shows six co-occurring haplotypes without geographic structuring. Four of these haplotypes are present in Canoe Beach, three in Reid State Park and two in Lubec (Supplementary Fig. 6). For ITS1, a major haplotype exists, with two minor haplotypes separated by only one substitution from the major haplotype.

\subsection{Morphological measurements and morphotypes}

A total of four morphotypes can be identified in Stygocapitella based on chaetal composition. All these morphotypes can be distinguished by

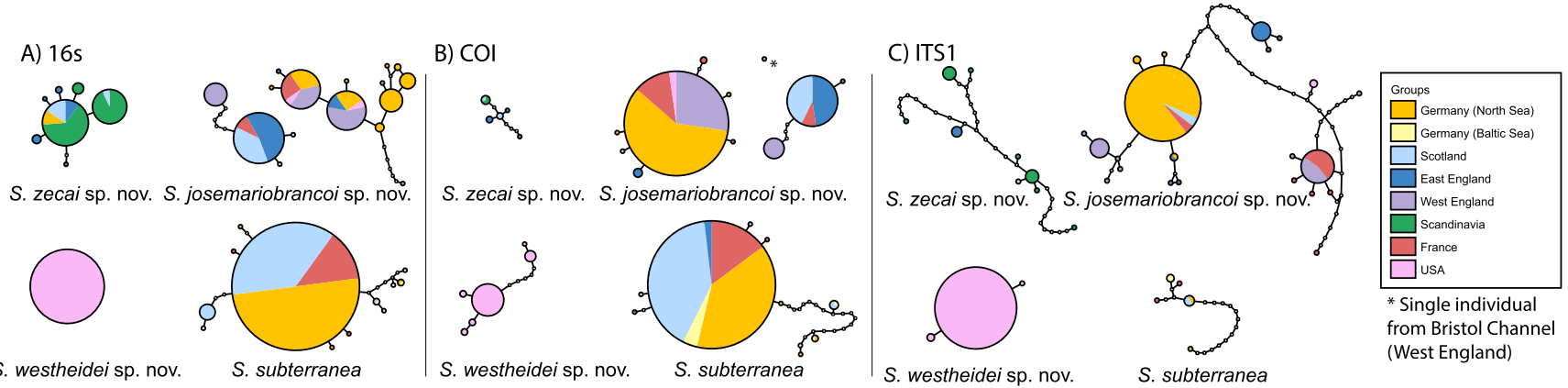

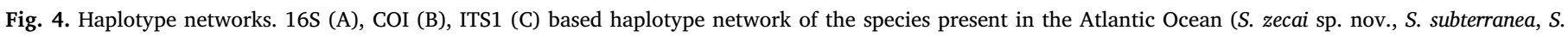
westheidei sp. nov., S. josemariobrancoi). Haplotype sp. nov. networks are colored based on countries and regions. 


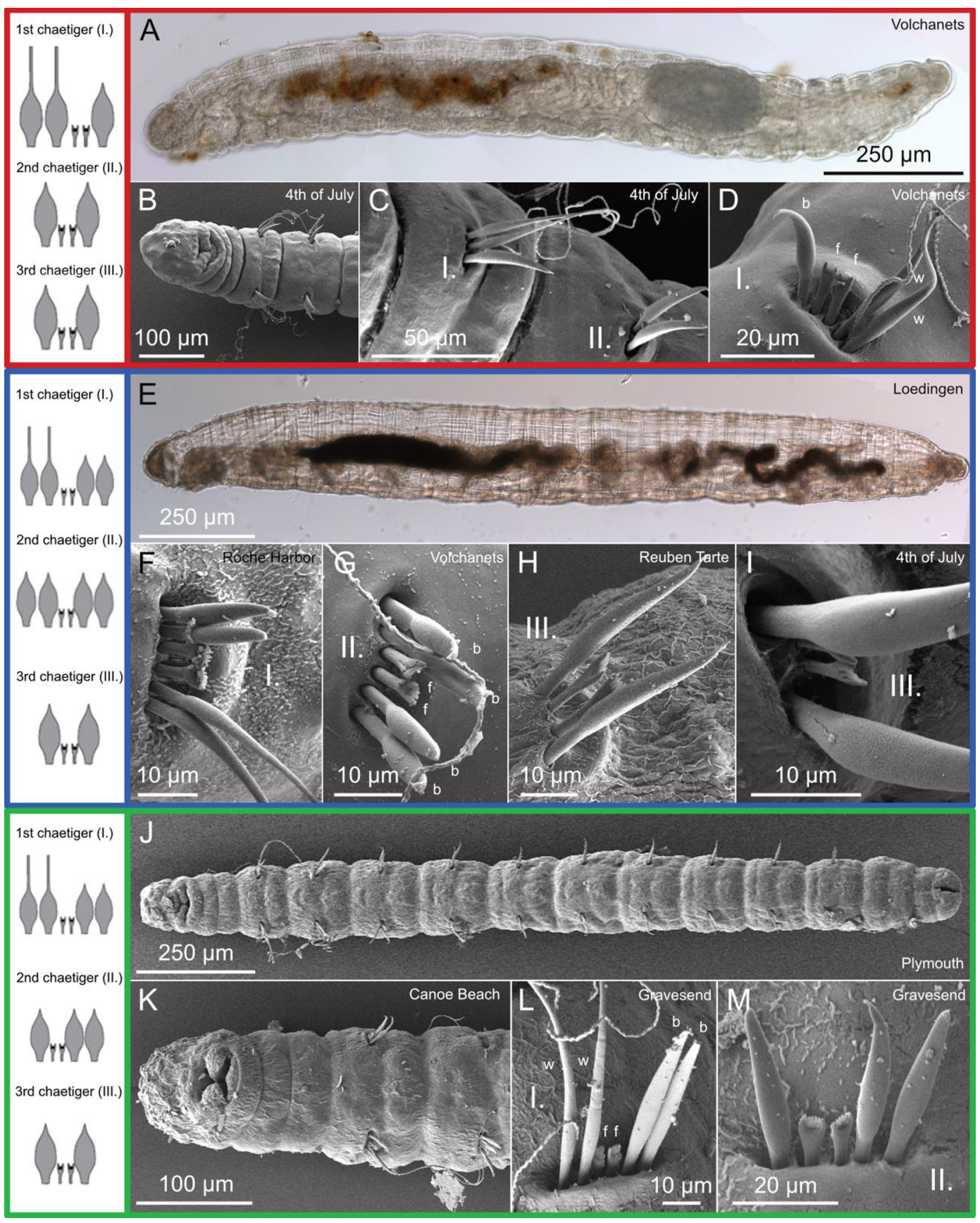

Fig. 5. Scanning electron microscopy and light microscopy images of Stygocapitella. Three morphotypes are represented in red, blue and green boxes (for species delimitation see also Fig. 2). (A) Light microscopy photograph of $S$. pacifica sp. nov. from Volchanets. (B \& C) SEM images of $S$. furcata sp. nov. from 4th of July Beach with first (I.) and second (II.) chaetae-bearing segments. (D) $1^{\text {st }}$ chaetiger of $S$. pacifica sp. nov. with two whip-like (w), two forked (f) and one bilimbate (b) chaetae. (E) Light microscopy photograph of S. zecai sp. nov. from Lødingen. (F) $1^{\text {st }}$ chaetiger of S. berniei sp. nov. from Roche Harbor with two whip-like, two forked and two bilimbate chaetae. (G) $2^{\text {nd }}$ chaetiger of $S$. budaevae sp. nov. from Volchanets with two bilimbate (b), two forked (f) and two bilimbate (b) chaetae. (H) $3^{\text {rd }}$ chaetiger of S. americae sp. nov. from Reuben Tarte. (I) $3^{\text {rd }}$ chaetiger of Stygocapitella from 4th of July Beach. (J) SEM images of whole S. josemariobrancoi sp. nov. from Plymouth. (K) Anterior end of $S$. westheidei sp. nov. from Canoe Beach. (L \& M) First two chaetigers of $S$. josemariobrancoi sp. nov. from Gravesend. $1^{\text {st }}$ chaetiger with two whiplike (w), two forked (f) and two bilimbate (b) chaetae. $2^{\text {nd }}$ chaetiger with one bilimbate (b), two forked (f) and two bilimbate (b) chaetae. (For interpretation of the references to color in this figure legend, the reader is referred to the web version of this article.)

chaetae number and composition of chaetae present in the first two chaetigers (Fig. 5). The first morphotype is specific to $S$. minuta (see Struck et al., 2017). It comprises two whip-like and three bilimbate chaetae in the first and four bilimbates in the second chaetiger. The second morphotype consists of two whip-like, two forked and one bilimbate chaetae in the first, and one bilimbate, two forked and one bilimbate chaetae in the second chaetiger (red morphotype in Fig. 5). This morphotype is seen in $S$. pacifica sp. nov., $S$. furcata sp. nov., and $S$. australis. The third morphotype is distinguished by its two whip-like, two forked and two bilimbate chaetae in the first and two bilimbate, two forked and two bilimbate chaetae in the second chaetiger (blue in Fig. 5). This morphotype is present in $S$. berniei sp. nov., S. americae sp. nov., S. budaevae sp. nov., S. zecai sp. nov. and presumably in Stygocapitella sp. A, for which we lack morphological data. The fourth morphotype is identified by two whip-like, two forked and two bilimbate chaetae in the first and one bilimbate chaetae, two forked and 
A)

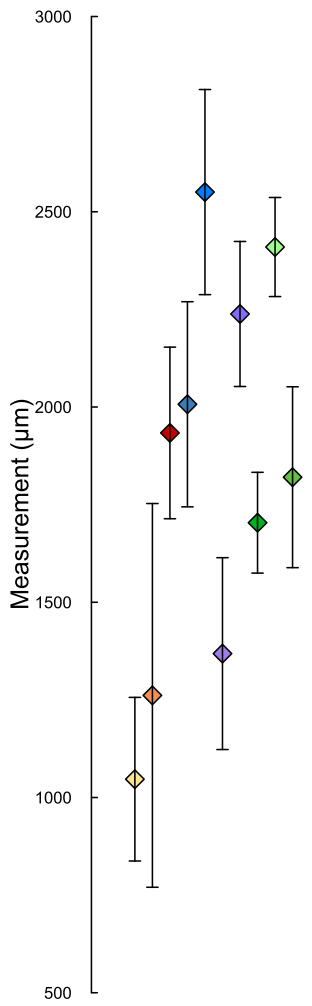

Body Length

B)

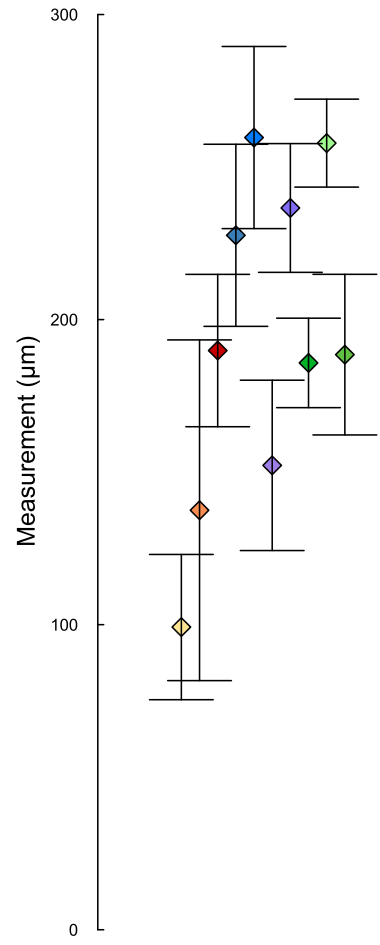

Body Width

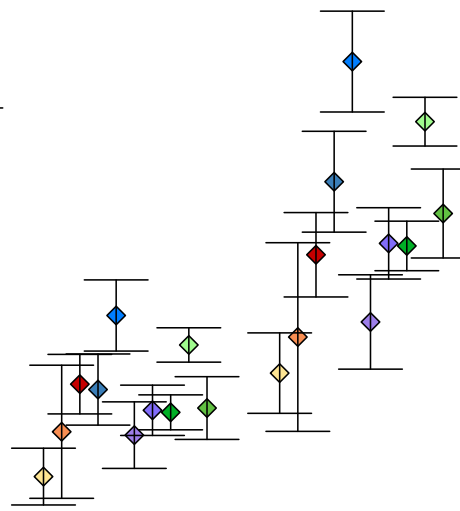

Prostomium Length
Stygocapitella minuta

Stygocapitella pacifica sp. nov

Stygocapitella australis

Stygocapitella berniei sp. nov

Stygocapitella americae sp. nov

Stygocapitella budaevae sp. nov

Stygocapitella zecai sp. nov

Stygocapitella subterranea (sensu stricto)

Stygocapitella josemariobrancoi sp. nov

Stygocapitella westheidei sp. nov

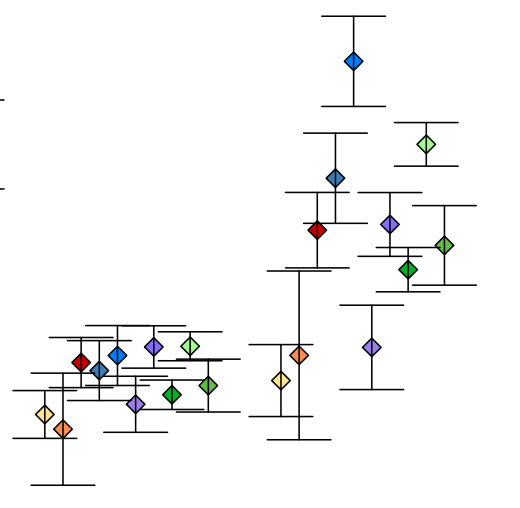

Pigidium Length

Pigidium Width

Different measurements

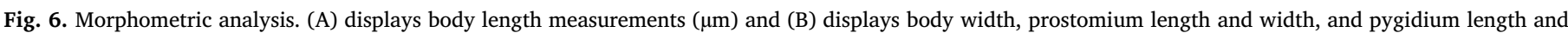
width $(\mu \mathrm{m})$.

two bilimbate chaetae in the second chaetiger (green in Fig. 5). This morphotype is present in $S$. josemariobrancoi sp. nov., $S$. westheidei sp. nov., and $S$. subterranea. All morphotypes have one bilimbate, two forked and one bilimbate chaetae in the third and following chaetigers except for that present in $S$. minuta, which only has bilimbate chaetae in these chaetigers.

General Linear Models demonstrate significant differences in measurements: body length (Likelihood Ratio Test scaled dev. $=124.72$, $p<0.001$ ), body width (LRT scaled dev. $=118.3, p<0.001$ ), prostomium length (LRT scaled dev. $=76.5, p<0.001$ ), prostomium width (LRT scaled dev. $=122.8, p<0.001$ ), pygidium length (LRT scaled dev. $=45.4, p<0.001$ ), and pygidium width (LRT scaled dev. $=140.5, p<0.001)$. Results from the morphological measurements show that pairwise differences in body length between species are also roughly reflected in the remaining five measurements (Fig. 6, Supplementary Table 4). Considering this, we will concentrate on body length in the following section. Most notably, $S$. minuta is significantly shorter in body length (mean 1046.88; SD 76.29) when compared to the remaining species, with the exception of $S$. pacifica sp. nov. (mean 1261.47; SD 52.21) and S. budaevae sp. nov. (mean 1368.49; SD 164.53). For the second morphotype mentioned above, we lack light microscopy-based measurement data for $S$. furcata sp. nov.. Within this morphotype, $S$. pacifica sp. nov. is smaller than $S$. australis (mean 1933.61; SD 218.01), but this difference is not statistically significant. For the third morphotype, $S$. budaevae sp. nov. has the shortest body length, followed by $S$. berniei sp. nov. (mean 2006.98; SD 436.99), whereas $S$. americae sp. nov. (mean 2550.4; SD 229.74) has the largest body length, followed by $S$. zecai sp. nov. (mean 2238.23; SD 322.48). In this way, $S$. budaevae sp. nov. is not significantly different in body length from $S$. berniei sp. nov., but it is significantly different from $S$. americae sp. nov. and $S$. zecai sp. nov.. Interestingly, $S$. berniei sp. nov. is not significantly different from all species with the third morphotype in any of the characters except for pygidium width, which is significantly different to $S$. budaevae sp. nov. (Suppl. Table 4). Stygocapitella americae sp. nov. and $S$. zecai sp. nov. are not significantly different in body length, but in prostomium length and width and pygidium width. Within the fourth morphotype from above, $S$. josemariobrancoi sp. nov. (mean 2409.7; SD 472.15) is clearly the longest species, while $S$. subterranea (mean 1703.7; SD 380.68) and S. westheidei sp. nov. (mean 1820.2; SD 293.68) have overlapping body length values. Accordingly, $S$. josemariobrancoi sp. nov. is significantly different from $S$. subterranea and $S$. westheidei sp. nov., but the latter two are not separated from each other.

Finally, we decomposed the variance in all data using principal component analyses. Considering all species together the first principal component separates only $S$. minuta from the remaining species (PC1 explains $75.4 \%$ of the variance; Fig. 7A). The second and third principal components explained $11.9 \%$ and $5.4 \%$ of the variance, respectively, but could not separate any of the species (data for third component not shown). However, when considering the variance within morphotypes, the results are slightly more informative. In the second morphotype, $S$. pacifica sp. nov. is clearly separated from $S$. australis based on the first principal component (Fig. 7B). However, S. pacifica sp. nov. is only represented by two specimens. In the third morphotype, the first principal component separates $S$. budaevae sp. nov. from the remaining three species (Fig. 7C). S. zecai sp. nov. can also be separated from $S$. americae sp. nov. based on the first two principal components, but both overlap substantially with $S$. berniei sp. nov.. Finally, in the fourth morphotype all three species overlap substantially, so that they cannot be separated based on the PCA analysis (Fig. 7D). This is not due to the 


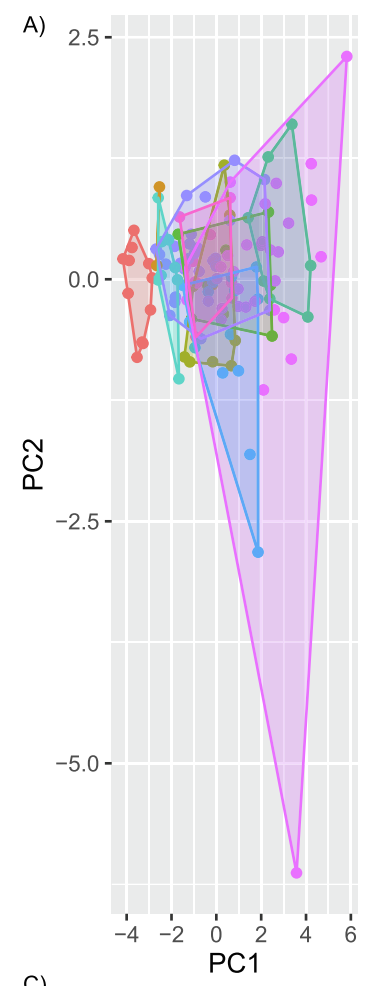

C)

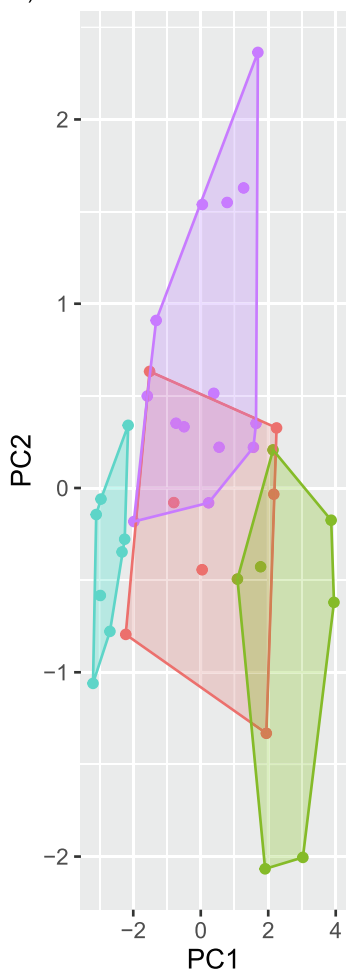

\section{Species}

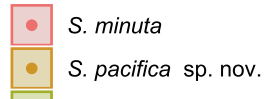

- S. australis

- S. berniei sp. nov.

- S. americae sp. nov.

- S. budaevae sp. nov.

- S. zecai sp. nov.

- S. subterranea (sensu stricto)

- S. josemariobrancoi sp. nov.

S. westheidei sp. nov.

\section{Species}

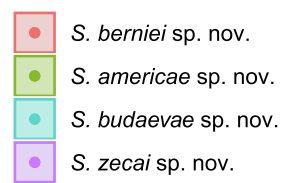

B)

B) 2 -

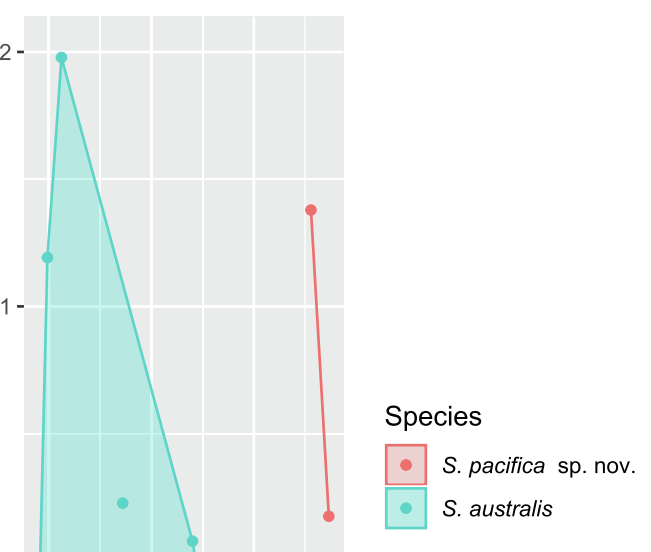

D)
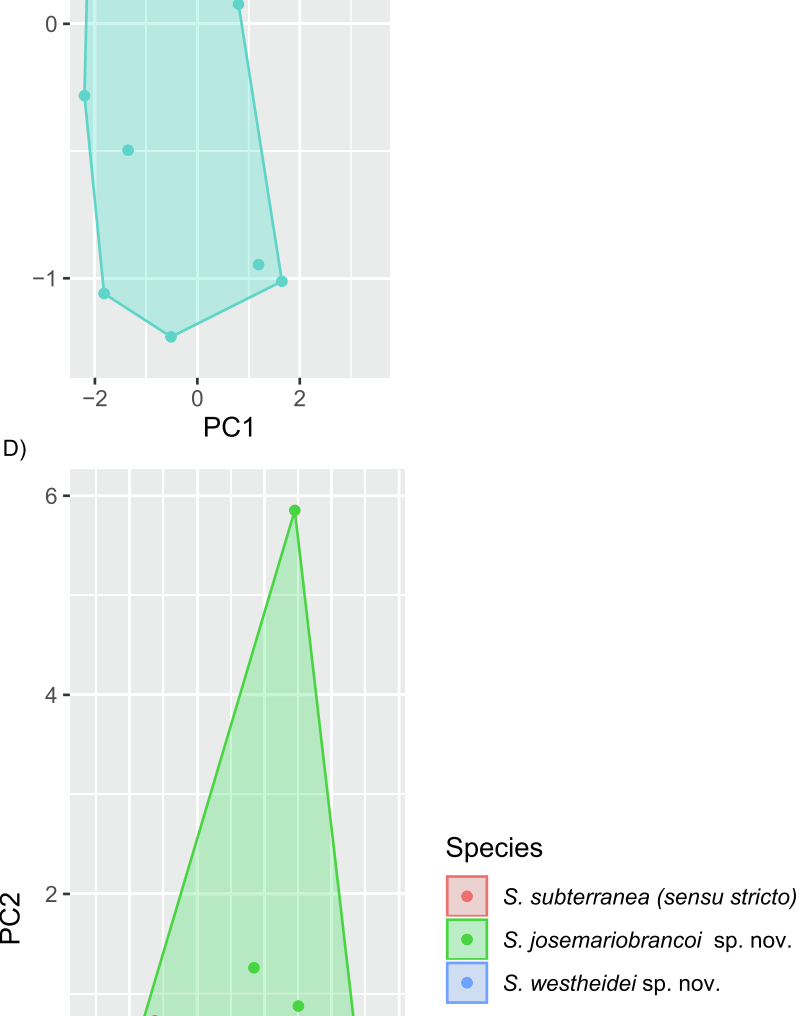

Fig. 7. Principal component analysis of morphological measurements. Every panel displays the first two principal components (PC1-PC2). (A) all species. (B), (C) and (D) species from separate morphotypes, respectively (see Fig. 5).

lack of data as these are the three species with highest number of sampled specimens.

\subsection{Species delimitation}

The complementary approaches to species delimitation were generally concordant (Fig. 2). With a total of 16 species, the GMYC algorithm (based on the Bayesian tree) was the method suggesting the most species, while, on the other hand, bPTP (based on the ML tree) proposed the least number of species (13). Every approach suggested that $S$. pacifica sp. nov., S. furcata sp. nov., S. berniei sp. nov., S. americae sp. nov., $S$. spec. A, and $S$. zecai sp. nov. all represent single taxonomic units. Stygocapitella minuta and $S$. budaevae sp. nov. are consistently considered as single species in all the approaches with the exception of 
COI networks which suggest the presence of two species in each of these lineages (Fig. 2). GMYC, bPTP, and network approaches suggest that $S$. australis represent two separate species. For $S$. josemariobrancoi sp. nov., COI networks and GMYC suggest the occurrence of three species, which also obtain support by posterior probabilities above 0.90 . On the other hand, $16 \mathrm{~S}$ networks suggest the occurrence of two species, but these were not recovered as monophyletic in the ML tree. Finally, bPTP suggests the occurrence of a single species. In both $S$. westheidei sp. nov. and $S$. subterranea, GMYC suggest two separate species, each of which also obtain posterior probabilities above 0.90 , whereas the remaining methods suggest the occurrence of only one species. To avoid over splitting, we have opted for a conservative approach in species recognition, which consisted in selecting species based on a most inclusive approach. That is, if one approach found a clade as single species, while another one as more than one, we regarded this clade as a single species. Additionally, the recognized species had to be retrieved as monophyletic, and strongly supported in all phylogenetic reconstructions of the concatenated datasets (for more details see Taxonomic account). Finally, high uncorrected COI distances $>25 \%$ between some of the species seem to reflect a very long history of evolution within the group with little morphological change associated (Supplementary Tables 5 and 6).

\section{Discussion}

We described the genetic divergence and morphological disparity among species in the Stygocapitella genus. We find four morphotypes based on chaetal number and composition in a total of 12 species, rendering some species morphologically identical. Even considering chaetal pattern (diagnostic feature) and light microscopy measurements (quantitative data), we are unable to distinguish species, which can only be distinguished using molecular tools. The morphological evolution of this species complex is exceptionally slow, as expected for cryptic species under morphological stasis (Cerca et al., 2018; Struck et al., 2018a; Struck and Cerca, 2019). With one exception, all Stygocapitella species occur in a single coastline, yet some of them are widely distributed spanning hundreds or thousands of kilometres. The discovery of cryptic species drastically reduced the cosmopolitan distribution of S. subterranea sensu lato (e.g. Purschke et al., 2019; Schmidt and Westheide, 2000; Westheide, 1990). We find indirect evidence for a potential oceanic translocation due to human activity in $S$. josemariobrancoi sp. nov. We discuss the relevance of morphology in taxonomy and the impact of cryptic species in marine biogeography.

\subsection{Cryptic species: Taxonomic artefacts or evolutionary phenomena?}

We describe eight new Stygocapitella species, totalling to eleven species in the genus. Additionally, one species is not yet formally described due to lack of type material, as required by the ICZN. While we find evidence for several morphologically similar species to occur, we identified four morphotypes based on the number and composition of chaetae in the first three chaetigers. Within each morphotype, clear differences in body measurements were found only between some species, but not all. For example, $S$. americae sp. nov. and $S$. berniei sp. nov. co-occur at the Pacific coastline of the US (Friday Harbor, Washington state), share the same morphotype and display no significant differences in quantitative measurements. The same is true for $S$. zecai sp. nov. and $S$. berniei sp. nov.. The only diagnosable difference between these two species is molecular divergence, and potentially their geographic distribution, yet considering the global raise in species introduction by humans (Barnes, 2002; Mack and Lonsdale, 2001; Radziejewska et al., 2006) this cannot be taken as a rigorous diagnostic character. A similar example occurs between $S$. subterranea and $S$. westheidei sp. nov., which cannot be differentiated from each other neither based on morphotype nor morphometrics, but only by molecular data. Finally, so far $S$. pacifica sp. nov., $S$. furcata sp. nov. and $S$. australis can also only be separated by molecular tools. We have thus provided evidence that in Stygocapitella morphology is very similar across different species and that some species are even impossible to be identified based on morphology alone. This calls into question whether these species can be called cryptic species or not.

The most often applied definition of cryptic species requires that a given group of species has been recognized as single species before: "two or more distinct species that are erroneously classified (and hidden) under one species name" (Bickford et al., 2007). This definition places the focus in the taxonomic history of the cryptic species complex (Struck and Cerca, 2019). Strictly under this definition, from the eight Stygocapitella species herein described (and the undescribed species), only seven could be considered cryptic species. These seven represent populations/sites which have been considered to be $S$. subterranea before in the literature (Karling, 1958; Knöllner, 1934; Purschke, 2006, 1999, 1987, 1986; Purschke et al., 2019; Purschke and Fursman, 2005; Purschke and Jördens, 2007; Riser, 1980; Schmidt and Westheide, 2000; Schmidt, 1972a, 1970, 1969; Struck et al., 2017; Westheide, 2008, 1966; Worsfold, 2008). The two only exceptions would be $S$. pacifica sp. nov. and $S$. budaevae sp. nov., which represent new records and have therefore never been identified as $S$. subterranea. This exposes the arbitrary nature of this definition, which has led some workers to argue that cryptic species are not a natural phenomenon, but rather artefacts of taxonomic practices such as, for instance, the lack or inappropriate resolution of morphological data to determine species boundaries (Korshunova et al., 2019, 2017).

It has been suggested that cryptic species should only be considered as a "temporary formalization of the problems with delineation of the species from the same geographic region, when those species demonstrate significant molecular phylogenetic differences, but are hardly distinguished morphologically, ethologically, etc." (Korshunova et al. 2017). Given this definition, which considers cryptic species as a problem, not all Stygocapitella species could be considered cryptic species. For instance, $S$. westheidei sp. nov. and $S$. subterranea are morphologically indistinguishable but are present at different coastlines. Following this definition would not solve the "problem" of morphological similarity between these two species because they do not geographically overlap. Importantly, and despite the efforts herein included to determine morphological differences between species, most Stygocapitella species lack diagnostic characters and morphological differences, which allow an unambiguous identification to the species level. Indeed, only when using molecular data, one is able to distinguish these species. Even when length measurements are significantly different between species, a substantial overlap between specimens often exists, which does not allow to unambiguously assign an individual to a species and is prone to errors if juveniles get measured. This is evidenced from the PCA, which considers all measurements simultaneously, yet species substantially overlap and are thus unable to be identified. A second critical aspect of this definition is its reliance on sympatry and geography. As we discuss below, we find potential evidence for a recent trans-oceanic translocation by human activity. While we are able to distinguish species based on measurements, if translocated specimens would have been from $S$. subterranea and not $S$. josemariobrancoi sp. nov. it would not be possible to distinguish them from the putatively native species $S$. westheidei sp. nov. without molecular data. Considering its reliance on geography, this definition fails to detect introduced species, when these are morphologically indistinguishable and creates arbitrary challenges on whether species are sympatric or not. Finally, an implicit assumption of this definition is that substantial phenotypic differences will accumulate between species, given enough evolutionary time. This is not the case, as shown by the evidence for long-lasting stasis in palaeontology (Eldredge and Gould, 1972; Futuyma, 2010), as well as in cryptic species complexes (Lee and Frost, 2002; Struck et al., 2017; Swift et al., 2016; Wada et al., 2013). This is evident after contrasting the genetic differences of Stygocapitella with its morphological evolution, hence being in line with the hypothesis of 
cryptic species complexes under stasis, as enough time has passed to allow for the accumulation of phenotypic differences. Despite this, few or no phenotypic differences can be observed. Treating these cases just as a taxonomic problems would overlook the phenomenon of morphological stasis (Lee and Frost, 2002; Struck et al., 2017; Swift et al., 2016; Wada et al., 2013).

An entirely different approach to delimit and understand cryptic species consists in recognising these as the result of evolutionary phenomena resulting in the deceleration of morphological evolution (Struck et al., 2018a, b). Based on this approach, first, a regular species delineation process takes place. This delimitation-step should focus on detecting differences between putative species and include various sorts of data such as ecological, behaviour and morphological data, being as scrupulous as possible. In a second step, an assessment of the species' morphological similarity should be done. This second step allows evaluating whether the species complex is indeed comprised of cryptic species (i.e. species morphologically more similar than expected). To determine if a set of species are more similar than expected, workers should focus on obtaining the time of divergence of the species complex, and, when possible, compare it with a closely related taxon/taxa (i.e. outgroup). By separating the species-delimitation (step 1), from the assignment of cryptic species (step 2), the assignment of cryptic species relies solely on the degree of morphological disparity, and on the time of divergence. This allows differentiating between taxonomic artefacts and the deceleration of morphological evolution as seen in cryptic species (Struck et al., 2018a). On the negative side, it requires an exhaustive understanding of the species complex as well as meticulous sampling and knowledge of the study system (Korshunova et al., 2019). While this might not be possible in every case, a scrupulous and meticulous approach is essential to define species, be it cryptic species or not. In Stygocapitella, as outlined above, only very little morphological differences can be observed despite pronounced genetic divergence. Treating these as mere taxonomic oddities would conceal a true biological phenomenon: morphological stasis (Struck et al., 2018a; Struck and Cerca, 2019; Swift et al., 2016; Wada et al., 2013). Recent estimates suggest that the evolution of the Stygocapitella genus has occurred in $>200$ million years and $S$. australis has been separated from $S$. subterranea for more than 80 million years (Struck et al., 2017). To put this into perspective, the whole radiation of mammals took place in less time. Orbiniidae, which is the sister family to Parergrodiliidae (which includes Stygocapitella), comprises 21 genera (Horton et al., 2019). This family has accumulated much more phenotypic differences in the same time than Stygocapitella. Therefore, Stygocapitella spp. are a textbook example of cryptic species.

\subsection{Delimiting cryptic species and biological diversity}

Six of the newly described Stygocapitella species were originally considered to be Stygocapitella subterranea, highlighting the necessity of proper species description in understanding marine biodiversity. The lack of taxonomic knowledge has consequences for marine conservation (Bernardo, 2011; Bickford et al., 2007; Costa and Carvalho, 2010; Schonrogge et al., 2002), biodiversity assessments (Appeltans et al., 2012; Hawksworth and Lücking, 2017; Meyer-Wachsmuth et al., 2014) and species distribution (Cerca et al., 2018). Ratios of 'crypticness' (i.e. proportion of cryptic species within described species) (Kon et al., 2007) seem to be high in the sea (Cerca et al., 2018; Knowlton, 1993). To name a few examples, 14 cryptic species in Brachionus plicatilis (Rotifera) (Suatoni et al., 2006), 10 cryptic species in Eumida sanguinea (phyllodocidan polychaetes) (Nygren and Pleijel, 2011), and 25 in four described Terebellides polychaete species (Nygren et al., 2018). These uncommonly high numbers result from issues related to the obstacles in sampling, re-sampling and identifying marine species (Hellberg, 2009; Knowlton, 2000, 1993), which ultimately jeopardize the understanding of basic biology, such as species distribution and life cycle. Cryptic species should be taken into account when protecting marine biodiversity as these contribute to overlooked species richness (Pante et al., 2015). Yet, we must point out that we can only be led to speculate how much biological diversity is missed due to the occurrence of cryptic species, especially having in mind that we cannot yet determine the proportion of cryptic species, which are only taxonomic artefacts (Korshunova et al., 2017; Struck et al., 2018b). Nonetheless, it is worth noticing that morphologically-based practices have failed to report this diversity. Estimations suggest that there might be ca. 9,000-36,000 cryptic species in the sea, comprising $3-12 \%$ of marine biodiversity (Appeltans et al., 2012). The development of new tools, including recent genomic approaches which have contributed towards closing the gap between population genetics and phylogenetics, is likely to benefit and improve species delimitation, including the delimitation of cryptic species (Singhal et al., 2018; Struck et al., 2018a). For example, new demographic tools allow distinguishing the contribution of gene flow and incomplete lineage sorting. In the brittle star Ophioderma longicauda the modelling of relatively complex demographic scenarios led to the delimitation of cryptic species in the face of strong incomplete lineage sorting and past hybridization events (Weber et al., 2019).

\subsection{Implications of cryptic species to marine biogeography}

The splitting of Stygocapitella subterranea sensu lato, originally described as a cosmopolitan species, into nine species with reduced geographical distributions suggests that overlooking cryptic species tends to inflate the distribution of marine organisms (Knowlton, 1993; Struck et al., 2018a). The wide distribution of many marine species (Cerca et al., 2018; Johannesson, 1988), and the paradoxical distribution of species with non-pelagic and pelagic larvae (Hellberg, 2009) remains as one of the most puzzling observations in marine biology. The potential high number and influence of cryptic species with reduced distribution ranges provides a further step to solve these issues. The results herein found are in line with evidence from other meiofaunal taxa, which demonstrate that delimitated cryptic species often have geographically restricted distributions and the range of individual species is smaller than the originally described species (Cerca et al., 2018). For instance, in the rotifer Brachionus plicatilis, the discovery of 14 cryptic species led to the reduction of the distribution of the originally described species. While the originally described species was recognised as a cosmopolitan species, cryptic lineages demonstrate a rather localized distribution (Suatoni et al., 2006). Similarly, the gastropod Pontohedyle milaschewitchii had been reported in the Indian Ocean, Central Pacific, Western Pacific, Eastern Pacific, Western Atlantic, and Eastern Atlantic including the Mediterranean and Black Sea. The splitting and discovery of six cryptic species led to the circumscription of one species to the Western Atlantic, another to the Indian Ocean, Central Pacific, Western Pacific, another to the Central Pacific, one to the Eastern Pacific, another to the Mediterranean and Black Sea, and yet another to the Eastern Atlantic (Jörger et al., 2012).

Despite the observed reduction of geographical distribution, Stygocapitella species still maintain wide distributions suggesting wide dispersal capacities. Species for which we obtained multiple specimens show no association between population structure and geography. For example, $S$. zecai sp. nov. is distributed from Northern Norway to Southern England and a 16S haplotype is shared between specimens from Henningsvær and Lødingen (Northern Norway), Ardtoe (Western Scotland) and Cutty Sark (England) suggesting that no population structure occurs for about $\sim 400 \mathrm{~km}$ distance. Similarly, the two remaining species occurring in Europe $(S$. subterranea and $S$. josemariobrancoi sp. nov) have wide distributions ranging from Scotland to Germany and France, with haplotypes occurring over long distances. Finally, $S$. westheidei sp. nov. has only a single $16 S$ haplotype along the entire North-western Atlantic coastline in the USA spanning $\sim 450 \mathrm{~km}$ (but notice COI). These distributions are coherent with recent evidence from meiofaunal nematodes (Derycke et al., 2008), nemerteans (Leasi and Norenburg, 2016, 2014), xenacoelomorphans (Meyer-Wachsmuth 
et al., 2014) and molluscs (Jörger et al., 2012), even after the discovery of cryptic species. Generally, the discovery of cryptic species in these groups led to the reduction of the first assigned distribution, but these lineages still maintain wide distribution ranges (Cerca et al., 2018).

The phylogeny of Stygocapitella displays a biogeographic signal related to oceanic water bodies. All Northern Atlantic species form a monophyletic group in all analyses. Interestingly, $S$. westheidei sp. nov., which occurs at the North-western Atlantic (American coastline), is nested within the remaining North-eastern Atlantic species (European coastline), suggesting a relatively recent oceanic transition. The Northern Atlantic group is placed among species occurring in the IndoPacific Oceans. This indicates that a transition from the Indo-Pacific to the Atlantic has occurred only once. Most prominently, we find evidence for sister species occurring in opposite sides of the Northern Pacific Ocean, with $S$. furcata sp. nov. and $S$. pacifica sp. nov. as well as Stygocapitella spec. A and $S$. budaevae sp. nov. occurring in Northern America and Russia, respectively. This potentially reveals that the ancient lineage of each pair could transverse the Pacific Ocean, or speciated allopatrically following vicariance.

Interestingly, the Australian species, Stygocapitella australis, nests among the Northern Pacific ones, while $S$. minuta, from South Africa, is the first to branch off in the phylogenetic tree. This suggests that at least two equatorial transitions must have occurred in addition to the oceanic transitions in the Northern hemisphere. Two major hypotheses have been suggested to explain the distribution of meiofaunal groups. These include the strict vicariance hypothesis, which assumes that these organisms are poor dispersers, and the long-distance dispersal hypothesis. Evidence gathered from this work is congruent with a previous analysis (Struck et al., 2017), which together suggest that a strict vicariance hypothesis does neither fit the observed distribution pattern, neither the phylogeny of these meiofaunal organisms. We find evidence for several events of long-distance dispersal (Westheide, 1991, 1977), which have an important role in establishing new populations across oceans and spreading along coastlines (Derycke et al., 2008; Schmidt and Westheide, 2000).

Two specimens collected in Lubec (Maine, USA) at the NorthWestern Atlantic coastline were identified as S. josemariobrancoi sp. nov. using molecular tools. This species is elsewhere only present along the Northern European coastline (Supplementary Fig. 1). The specimens from Lubec share a 16S haplotype with specimens from England, France and Germany. This suggests a very recent dispersal event possibly due to trans-Atlantic trade. Even though we have no evidence to conclude that this translocation was human-based, this result is in line with evidence suggesting that meiofaunal specimens can be dispersed by ballast water or sand translocations (Radziejewska et al., 2006).

\section{Taxonomic account}

We did not take any formal taxonomic actions for Stygocapitella spec. A as we lack material for morphological studies and hence cannot assign type material for this species. We do not take any taxonomic actions on $S$. australis despite some analyses suggesting they are potentially different species, for example, large uncorrelated COI distance within $S$. australis specimens (Supplementary Tables 5 and 6). Describing both as separate species could entail that one of them would be non-monophyletic (see Fig. 2). More Western Australian data are needed to solve this issue. Records from New Zealand (Riser, 1984) should also to be taken into account by collection of fresh material for molecular analyses. Interspecific pairwise genetic distances between the species are found in Supplementary Table 5, intraspecific genetic distances are found in Supplementary Table 6. Described species have been registered in in Zoobank.org.

Genus Stygocapitella Knöllner, 1934

Type species Stygocapitella subterranea Knöllner, 1934 (sensu stricto)

Stygocapitella subterranea (Karling, 1958; Knöllner, 1934; Purschke,
2006, 1999, 1987, 1986; Purschke et al., 2019; Purschke and Fursman, 2005; Purschke and Jördens, 2007; Schmidt and Westheide, 2000; Schmidt, 1969, 1970; Struck et al., 2017; Westheide, 2008, 1966).

Types and material examined. See Struck et al. (2017).

Diagnosis: See Struck et al. (2017).

Description. See Struck et al. (2017) except for size:body length: mean $1703.7 \mu \mathrm{m}$ (range 2441.8-1099.2 $\mu \mathrm{m}$ ) and width $185.8 \mu \mathrm{m}$ (285.8-121.3 $\mu \mathrm{m})$; prostomium length $62.4 \mu \mathrm{m}(90-33.1 \mu \mathrm{m})$ and width

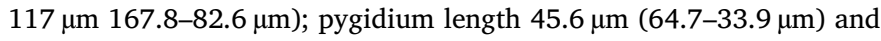
width $86.6 \mu \mathrm{m}(160.3-54.1 \mu \mathrm{m})$ (Fig. 6).

Habitat. See Struck et al. (2017).

Distribution. Restricted to the North-eastern Atlantic comprising the North Sea (British \& German coast), the Baltic Sea (German \& Southern Swedish coast), and the Eastern Atlantic Ocean (British \& French coast; Suppl. Fig. 1, Suppl. Table 1).

Remarks. The records from the Mediterranean Sea (French \& Tunisian coast), the Black Sea (Romanian coast) and New Zealand in the Southern hemisphere have also been assigned to $S$. subterranea before, but given the results herein it is uncertain whether these records belong to $S$. subterranea, $S$. josemariobrancoi sp. nov., $S$. westheidei sp. nov. or $S$. australis or even constitute new species. Therefore, these records should be considered as Stygocapitella sp. for the time being.

Stygocapitella pacifica sp. nov.

Types and material examined. Holotype: Volchanets, Russia, $\mathrm{N}$ $42^{\circ} 54^{\prime} 37.7^{\prime \prime} / \mathrm{E} 132^{\circ} 44^{\prime} 25.0^{\prime \prime}, 5.5 \mathrm{~m}$ above high-water line at a depth of $0-15 \mathrm{~cm}$, Coll. Natural History Museum of the University of Oslo (NHMO C6996). Additional material: One paratype from Volchanets, Russia, N 42 $54^{\prime} 37.7^{\prime \prime} / \mathrm{E} 132^{\circ} 44^{\prime} 25.0^{\prime \prime}, 5.5 \mathrm{~m}$ above high-water line at a depth of $0-15 \mathrm{~cm}$, Coll. Natural History Museum of the University of Oslo (NHMO C69967).

Type locality. Volchanets, Russia, N 42 $54^{\prime} 37.7^{\prime \prime} / \mathrm{E} 132^{\circ} 44^{\prime} 25.0^{\prime \prime}$

Diagnosis. Morphology: The first chaetiger possesses two bilimbate chaetae with a whip-like extension, one bilimbate and two forked chaetae, and all following ones two bilimbate and two forked chaetae. For genetic data see Genbank ID MN158611 (COI), MN164341 (16S).

Description. Color: White-transparent with a slightly iridescence surface. Size: body length: mean $1261.5 \mu \mathrm{m}$ (range 1298.4-1224.6 $\mu \mathrm{m}$ ) and width $137.5 \mu \mathrm{m}(141.1-133.9 \mu \mathrm{m})$; prostomium length $56 \mu \mathrm{m}$ $(62.9-49.2 \mu \mathrm{m})$ and width $87.1 \mu \mathrm{m}(92.7-81.5 \mu \mathrm{m})$; pygidium length $34.3 \mu \mathrm{m}(38.7-29.8 \mu \mathrm{m})$ and width $58.5 \mu \mathrm{m}$ (58.9-58.1 $\mu \mathrm{m})$ (Fig. 6). The body comprises a prostomium without appendages, a peristomium bearing the mouth opening, 13 segments and a round pygidium. $1^{\text {st }}$ to $12^{\text {th }}$ segment biannulated. Chaetae in pairs of ventrolateral bundles are present at segments $2-11$ in the first ring of each segment. First chaetiger with two bilimbate chaetae with whip-like extensions, two forked chaetae and one bilimbate chaeta in each bundle. All following chaetigers possess two bilimbate and two forked chaetae in each bundle.

Habitat: We found specimens at a beach with medium-sized sand grains at or above the high water level down to a depth of $20 \mathrm{~cm}$.

Distribution: Volchanets (Primorsky Krai region, Russia)

Etymology. The species name derives from presence in the Pacific Ocean.

Stygocapitella furcata sp. nov.

Stygocapitella subterranea partim (Purschke, 2006, 1999; Purschke et al., 2019; Schmidt and Westheide, 2000; Struck et al., 2017; Westheide, 2008), not Köllner 1934.

Types and material examined. Holotype: 4th July Beach, USA (WA), N 48 $28^{\prime} 05.6^{\prime \prime} / \mathrm{W} 123^{\circ} 00^{\prime} 10.7^{\prime \prime}$, between $5 \mathrm{~m}$ above high-water line and the high-water line, at a depth of $0-15 \mathrm{~cm}$, Coll. Natural History Museum of the University of Oslo (NHMO C7010). Additional material: One paratype from Roche Harbor, USA (WA), N 48 $35^{\prime} 46.0^{\prime \prime}$ / W $123^{\circ} 10^{\prime} 12.03 \mathrm{~m}$ above high-water line, at a depth of 0-20 cm. Coll. Natural History Museum of the University of Oslo (NHMO C7009). Besides the holotype and paratype, two specimens for molecular work have been examined.

Type locality. 4th July Beach, USA (WA), N $48^{\circ} 28^{\prime} 05.6^{\prime \prime} / \mathrm{W} 123^{\circ}$ 
$00^{\prime} 10.7^{\prime \prime}$

Diagnosis. For morphology see $S$. pacifica sp. nov.. For genetic data see Genbank ID: MN158612 (COI), MN164343 (16S).

Description. Color: White-transparent with a slightly iridescence surface. The body comprises a prostomium without appendages, a peristomium bearing the mouth opening, 13 segments and a round pygidium. $1^{\text {st }}$ to $12^{\text {th }}$ segment biannulated. Chaetae in pairs of ventrolateral bundles are present at segments 2-11 in the first ring of each segment. First chaetiger with two bilimbate chaetae with whip-like extensions, two forked chaetae and one bilimbate chaeta in each bundle. All following chaetigers possess two bilimbate and two forked chaetae in each bundle. No measurements were obtained for this species.

Habitat. Specimens predominantly occur at beaches with mediumsized sand grains at or above the higher water level up.

Distribution. San Juan Island (WA, USA). If the additional records from the North-Eastern Pacific along the US and Canadian Pacific coast (Purschke, 2006, 1999; Purschke et al., 2019; Schmidt and Westheide, 2000; Westheide, 2008) belong to this species, $S$. berniei sp. nov., or $S$. americae sp. nov. or constitute new species altogether is uncertain. Therefore, these records should be considered as Stygocapitella sp. for the time being.

Etymology. The species name reflects its having forked chaetae.

Stygocapitella berniei sp. nov.

Stygocapitella subterranea partim (Purschke, 2006, 1999; Purschke et al., 2019; Schmidt and Westheide, 2000; Struck et al., 2017; Westheide, 2008), not Köllner 1934.

Types and material examined. Holotype: Roche Harbor, USA (WA), $\mathrm{N} 48^{\circ} 35^{\prime} 46.0^{\prime \prime} / \mathrm{W} 123^{\circ} 10^{\prime} 12.0^{\prime \prime}$, between $3 \mathrm{~m}$ above high-water line and the high-water line, at a depth of $0-20 \mathrm{~cm}$, Coll. Natural History Museum of the University of Oslo (NHMO C6994). Aditional

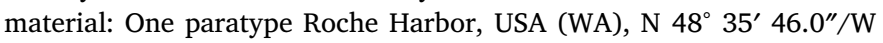
$123^{\circ} 10^{\prime} 12.0^{\prime \prime}$, between $3 \mathrm{~m}$ above high-water line and the high-water line, at a depth of $0-20 \mathrm{~cm}$, Coll. Natural History Museum of the University of Oslo (NHMO C6995). Besides the holotype and the paratype, 10 specimens for molecular work and two for SEM have examined.

Type locality. Roche Harbor, USA (WA), N $48^{\circ} 35^{\prime} 46.0^{\prime \prime} / \mathrm{W} 123^{\circ}$ $10^{\prime} 12.0^{\prime \prime}$

Diagnosis. Morphology: The first chaetigerous segment possesses two bilimbate chaetae with a whip-like extension, two bilimbate and two forked chaetae. The second segment possesses two bilimbate, followed by two forked, followed by two bilimbate chaetae. The third and remaining segments have two bilimbate and two forked chaetae organized in a bilimbate-forked-forked-bilimbate arrangement. For genetic data please see genbank IDs MN158602 (COI), MN164081 (16S).

Description. Color: White-transparent with a slightly iridescence surface. Size: body length: mean $1926.3 \mu \mathrm{m}$ (range 2552.8-1680.1 $\mu \mathrm{m}$ ) and width $217.5 \mu \mathrm{m}(273.7-203.63 \mu \mathrm{m})$; prostomium length $67.7 \mu \mathrm{m}$ (95.5-42.9 $\mu \mathrm{m})$ and width $132.7 \mu \mathrm{m}(182.2-86.7 \mu \mathrm{m})$; pygidium length $52.6 \mu \mathrm{m}(70.9-48 \mu \mathrm{m})$ and width $112.3 \mu \mathrm{m}(145.8-95.9 \mu \mathrm{m})$ (Fig. 6). The body comprises a prostomium without appendages, a peristomium bearing the mouth opening, 13 segments and a round pygidium. $1^{\text {st }}$ to $12^{\text {th }}$ segment biannulated. Chaetae in pairs of ventrolateral bundles are present at segments $2-11$ in the first ring of each segment. First chaetiger with two bilimbate chaetae with whip-like extensions, two forked chaetae and two bilimbate chaeta in each bundle. All following chaetigers possess two bilimbate and two forked chaetae in each bundle, except for the second one with four bilimbate chaetae.

Habitat. Specimens predominantly occur at beaches with mediumsized sand grains at or above the high-water line.

Distribution. San Juan Island (WA, USA). If the additional records from the North-Eastern Pacific along the US and Canadian Pacific coast (Purschke, 2006, 1999; Purschke et al., 2019; Schmidt and Westheide, 2000; Westheide, 2008) belong to $S$. furcata sp. nov., or $S$. americae sp. nov. or constitute new species altogether is uncertain. Therefore, these records should be considered as Stygocapitella sp. for the time being.

Etymology. The species name reflects upon field collection. The field collection site is in a private property, and while collecting, the caretaker of the property mentioned we could collect sand as long as we would support a progressive such as Bernie Sanders. The species honours Bernie Sanders for his efforts of inclusiveness, diversity and protection of minorities and underrepresented groups.

Stygocapitella americae sp. nov.

Stygocapitella subterranea partim (Purschke, 2006, 1999; Purschke et al., 2019; Schmidt and Westheide, 2000; Struck et al., 2017; Westheide, 2008), not Köllner 1934.

Types and material examined. Holotype: Reuben Tarte State Park, USA (WA), N $48^{\circ} 28^{\prime} 05.6^{\prime \prime} / \mathrm{W} 123^{\circ} 00^{\prime} 10.7^{\prime \prime}$, between $5 \mathrm{~m}$ above high-water line and the high-water line, at a depth of $0-15 \mathrm{~cm}$ Coll. Natural History Museum of the University of Oslo (NHMO C6992). Additional material: One paratype from Reuben Tarte State Park, USA (WA), N 48 $28^{\prime} 05.6^{\prime \prime} / \mathrm{W} 123^{\circ} 00^{\prime} 10.7^{\prime \prime}$, between $5 \mathrm{~m}$ above high-water line and the high-water line, at a depth of $0-15 \mathrm{~cm}$. Coll. Natural History Museum of the University of Oslo (NHMO C6993). Besides the holotype and the paratype, 14 specimens for molecular work and two for SEM have examined.

Type Locality. Reuben Tarte State Park, USA (WA), N $48^{\circ} 28^{\prime}$ $05.6^{\prime \prime} / \mathrm{W} 123^{\circ} 00^{\prime} 10.7^{\prime \prime}$

Diagnosis. For morphology see $S$. berniei sp. nov.. For genetic data see Genbank ID: MN158590 (COI); MN164069 (16S).

Description. Color: White-transparent with a slightly iridescence surface. Size: body length: mean $2007 \mu \mathrm{m}$ (range 2552.8-1342.9 $\mu \mathrm{m}$ ) and width $227.6 \mu \mathrm{m}(273.7-166.7 \mu \mathrm{m})$; prostomium length $69.9 \mu \mathrm{m}$ (95.5-42.9 $\mu \mathrm{m})$ and width $138 \mu \mathrm{m}(182.2-86.7 \mu \mathrm{m})$; pygidium length $53.5 \mu \mathrm{m}(70.9-39.4 \mu \mathrm{m})$ and width $116.5 \mu \mathrm{m}$ (145.8-74.9 $\mu \mathrm{m})$ (Fig. 6). The body comprises a prostomium without appendages, a peristomium bearing the mouth opening, 13 segments and a round pygidium. $1^{\text {st }}$ to $12^{\text {th }}$ segment biannulated. Chaetae in pairs of ventrolateral bundles are present at segments $2-11$ in the first ring of each segment. First chaetiger with two bilimbate chaetae with whip-like extensions, two forked chaetae and two bilimbate chaeta in each bundle. All following chaetigers possess two bilimbate and two forked chaetae in each bundle, except for the second one with four bilimbate chaetae.

Habitat. Specimens predominantly occur at beaches with mediumsized sand grains at or above the high-water line.

Distribution: San Juan Island (WA, USA). If the additional records from the North-Eastern Pacific along the US and Canadian Pacific coast (Purschke, 2006, 1999; Purschke et al., 2019; Schmidt and Westheide, 2000; Westheide, 2008) belong to this species, $S$. furcata sp. nov., or $S$. berniei sp. nov. or constitute new species altogether is uncertain. Therefore, these records should be considered as Stygocapitella sp. for the time being.

Etymology. The species name follows the American continent, where it was collected.

Stygocapitella budaevae sp. nov.

Types and material examined. Holotype: Volchanets, Russia, $\mathrm{N}$ $42^{\circ} 54^{\prime} 37.7^{\prime \prime} / \mathrm{E} 132^{\circ} 44^{\prime} 25.0^{\prime \prime}, 4.0 \mathrm{~m}$ above high-water line at a depth of $15-30 \mathrm{~cm}$, Coll. Natural History Museum of the University of Oslo (NHMO C6990). Additional material: One paratype Volchanets, Russia, $\mathrm{N} 42^{\circ} 54^{\prime} 37.7^{\prime \prime} / \mathrm{E} 132^{\circ} 44^{\prime} 25.0^{\prime \prime}, 4.0 \mathrm{~m}$ above high-water line at a depth of $0-15 \mathrm{~cm}$. Coll. Natural History Museum of the University of Oslo (NHMO C6991). Besides the holotype and paratype, 18 specimens for molecular work and two for SEM have examined.

Type locality. Volchanets, Russia, N 42 $54^{\prime} 37.7^{\prime \prime} / \mathrm{E} 132^{\circ} 44^{\prime} 25.0^{\prime \prime}$

Diagnosis: For morphology see $S$. berniei sp. nov. For genetic data check genbank Ids MN158380 (COI), MN164048 (16S)

Description. Color: White-transparent with a slightly iridescence surface. Size: body length: mean $1368.5 \mu \mathrm{m}$ (range 1655-1141 $\mu \mathrm{m}$ ) and width $152.2 \mu \mathrm{m} \quad(167.7-131.5 \mu \mathrm{m})$; prostomium length $55 \mu \mathrm{m}$ (62.1-46.8 $\mu \mathrm{m})$ and width $92 \mu \mathrm{m}$ (97.6-87.9 $\mu \mathrm{m})$; pygidium length $42.4 \mu \mathrm{m}(62.9-28.2 \mu \mathrm{m})$ and width $61.1 \mu \mathrm{m}$ (76.6-45.2 $\mu \mathrm{m})$ (Fig. 6). 
The body comprises a prostomium without appendages, a peristomium bearing the mouth opening, 13 segments and a round pygidium. $1^{\text {st }}$ to $12^{\text {th }}$ segment biannulated. Chaetae in pairs of ventrolateral bundles are present at segments 2-11 in the first ring of each segment. First chaetiger with two bilimbate chaetae with whip-like extensions, two forked chaetae and two bilimbate chaeta in each bundle. All following chaetigers possess two bilimbate and two forked chaetae in each bundle, except for the second one with four bilimbate chaetae.

Habitat: Specimens occurred at a beach with medium-sized sand grains at or above the higher water level up to a depth of $20 \mathrm{~cm}$.

Distribution. Volchanets (Primorsky Krai region, Russia)

Etymology. The species name honours the Russian polychaete biologist Nataliya Budaeva for her contributions to annelid systematics.

Stygocapitella zecai sp. nov.

Stygocapitella subterranea partim (Purschke, 2006, 1999; Purschke et al., 2019; Schmidt, 1972b, 1970, 1969; Struck et al., 2017; Westheide, 2008; Worsfold, 2008), not Köllner 1934.

Types and material examined. Holotype: Henningsvær, Norway, $68^{\circ} 15^{\prime} 38.8^{\prime \prime} \mathrm{N} 14^{\circ} 16^{\prime} 06.1^{\prime \prime} \mathrm{E}$ between high-water line and $6 \mathrm{~m}$ above the high-water line, at a depth of 0-15 cm Coll. Natural History Museum of the University of Oslo (NHMO C6988). Additional material: One paratype from Henningsvær $68^{\circ} 15^{\prime} 38.8^{\prime \prime} \mathrm{N} 14^{\circ} 16^{\prime} 06.1^{\prime \prime} \mathrm{E}$ between $6 \mathrm{~m}$ above high-water line and high-water line, at a depth of $0-15 \mathrm{~cm}$. Coll. Natural History Museum of the University of Oslo (NHMO C6989). Besides the holotype and paratype, 47 specimens for molecular work and two for SEM have examined.

Type locality. Henningsvær, Norway, $68^{\circ} 15^{\prime} 38.8^{\prime \prime} \mathrm{N} 14^{\circ} 16^{\prime} 06.1^{\prime \prime} \mathrm{E}$

Diagnosis. For morphology see $S$. berniei sp. nov.. For genetic data please see Genbank ID MN164099 (16S).

Description. Color: White-transparent with a slightly iridescence surface. Size: body length: mean $2238.2 \mu \mathrm{m}$ (range 2573.3-1514.3 $\mu \mathrm{m}$ ) and width $236.6 \mu \mathrm{m}(295.5-170.5 \mu \mathrm{m})$; prostomium length $63.1 \mu \mathrm{m}$ (85.3-44.3 $\mu \mathrm{m})$ and width $117.8 \mu \mathrm{m}(147.9-96.7 \mu \mathrm{m})$; pygidium length $61.2 \mu \mathrm{m}(100.8-45.9 \mu \mathrm{m})$ and width $101.4 \mu \mathrm{m}(126-69.7 \mu \mathrm{m})$ (Fig. 6). The body comprises a prostomium without appendages, a peristomium bearing the mouth opening, 13 segments and a round pygidium. $1^{\text {st }}$ to $12^{\text {th }}$ segment biannulated. Chaetae in pairs of ventrolateral bundles are present at segments $2-11$ in the first ring of each segment. First chaetiger with two bilimbate chaetae with whip-like extensions, two forked chaetae and two bilimbate chaeta in each bundle. All following chaetigers possess two bilimbate and two forked chaetae in each bundle, except for the second one with four bilimbate chaetae.

Habitat. Specimens predominantly occur at beaches with mediumsized sand grains at or above the high-water line, especially at beaches with low tidal exposure.

Distribution. The distribution is predominantly in the Northern Atlantic comprising the Northern and North Seas (Scandinavian, British \& German coast) (Supplementary Fig. 1).

Etymology. While collecting in Henningsvær, JC was hearing Zeca Afonso, an important freedom fighter whose songs inspired generations. The name honors him.

Stygocapitella josemariobrancoi sp. nov.

Stygocapitella subterranea partim (Purschke, 2006, 1999; Purschke et al., 2019; Schmidt, 1970, 1969; Struck et al., 2017; Westheide, 2008, 1966; Worsfold, 2008), not Köllner 1934.

Types and material examined. Holotype: Plymouth Bay, $50^{\circ} 20^{\prime} 55.0^{\prime \prime} \mathrm{N} 4^{\circ} 12^{\prime} 02.6^{\prime \prime} \mathrm{W}$ between high-water line and one meter above, at a depth of $0-15 \mathrm{~cm}$. Coll. Natural History Museum of the University of Oslo (NHMO C6986). Additional material: One paratype Plymouth Bay, between high-water line and one meter above, at a depth of $0-15 \mathrm{~cm}, 50^{\circ} 20^{\prime} 55.0^{\prime \prime} \mathrm{N} 4^{\circ} 12^{\prime} 02.6^{\prime \prime} \mathrm{W}$. Coll. Natural History Museum of the University of Oslo (NHMO C6987). Besides the holotype, paratype and mature additional material 97 specimens for molecular work and two for SEM have examined.

Type locality. Plymouth Bay, 50 $20^{\prime} 55.0^{\prime \prime} \mathrm{N} 4^{\circ} 12^{\prime} 02.6^{\prime \prime} \mathrm{W}$

Diagnosis. For morphology, see $S$. subterranea. For genetic data, see
Genbank ID MN158471 (COI); 16S (MN164224).

Description. Color: White-transparent with a slightly iridescence surface. Size: body length: mean $2409.7 \mu \mathrm{m}$ (range 3751.9-1317 $\mu \mathrm{m}$ ) and width $257.8 \mu \mathrm{m} 423.7-159.6 \mu \mathrm{m}$ ); prostomium length $84.5 \mu \mathrm{m}$ (153.3-48 $\mu \mathrm{m})$ and width $157.7 \mu \mathrm{m}(222.1-104.5 \mu \mathrm{m})$; pygidium length $61.5 \mu \mathrm{m}(160.3-39.1 \mu \mathrm{m})$ and width $127.6 \mu \mathrm{m}$ (163.4-97.4 $\mu \mathrm{m})$ (Fig. 6). The body comprises a prostomium without appendages, a peristomium bearing the mouth opening, 13 segments and a round pygidium. $1^{\text {st }}$ to $12^{\text {th }}$ segment biannulated. Chaetae in pairs of ventrolateral bundles are present at segments $2-11$ in the first ring of each segment. First chaetiger with two bilimbate chaetae with whip-like extensions, two forked chaetae and two bilimbate chaeta in each bundle. The second chaetiger with three bilimbate and two forked chaetae and all following ones with two bilimbate and two forked.

Habitat. Specimens predominantly occur at beaches with mediumsized sand grains at or above the high-water line, especially at beaches with low tidal exposure.

Distribution. The distribution is predominantly in the North Sea (British \& German coast) and the Channel (British \& French coast) (Supplementary Fig. 1). Two individuals were also found in Lubec (ME, USA).

Etymology. The name honors José Mário Branco, an important Portuguese singer whose music inspired whole generations. JC was hearing his music in the field.

Stygocapitella westheidei sp. nov.

Stygocapitella subterranea partim, (Purschke, 2006, 1999; Purschke et al., 2019; Riser, 1980; Schmidt and Westheide, 2000; Struck et al., 2017; Westheide, 2008) not Köllner 1934.

Types and material examined. Holotype: Canoe beach, $42^{\circ} 25^{\prime} 10.6^{\prime \prime} \mathrm{N} 70^{\circ} 54^{\prime} 24.6^{\prime \prime} \mathrm{W}$ between 5 and $7 \mathrm{~m}$ above high-water line in a depth of $0-30 \mathrm{~cm}$, Coll. Natural History Museum of the University of Oslo (NHMO C6984). Additional material: One paratype Canoe beach, $42^{\circ} 25^{\prime} 10.6^{\prime \prime} \mathrm{N} 70^{\circ} 54^{\prime} 24.6^{\prime \prime} \mathrm{W}$ between 5 and $7 \mathrm{~m}$ above highwater line in a depth of $0-30 \mathrm{~cm}$. Coll. Natural History Museum of the University of Oslo (NHMO C 6985). Besides the holotype, and paratype, 36 specimens for molecular work and two for SEM have examined.

Type locality. Canoe beach, $42^{\circ} 25^{\prime} 10.6^{\prime \prime} \mathrm{N} 70^{\circ} 54^{\prime} 24.6^{\prime \prime} \mathrm{W}$

Diagnosis. For morphology see $S$. subterranea. For genetic data see Genbank IDs MN158481 (COI) and MN164233 (16S)

Description. Color: White-transparent with a slightly iridescence surface. Size: body length: mean $1820.2 \mu \mathrm{m}$ (range 2299-1521.3 $\mu \mathrm{m}$ ) and width $188.5 \mu \mathrm{m}(237.2-147.4 \mu \mathrm{m})$; prostomium length $63.8 \mu \mathrm{m}$ $(73.4-49.2 \mu \mathrm{m})$ and width $127.6 \mu \mathrm{m}(168.3-105.9 \mu \mathrm{m})$; pygidium length $48.6 \mu \mathrm{m}(59.3-34.9 \mu \mathrm{m})$ and width $94.5 \mu \mathrm{m}(121.9-72.2 \mu \mathrm{m})$ (Fig. 6). The body comprises a prostomium without appendages, a peristomium bearing the mouth opening, 13 segments and a round pygidium. $1^{\text {st }}$ to $12^{\text {th }}$ segment biannulated. Chaetae in pairs of ventrolateral bundles are present at segments $2-11$ in the first ring of each segment. First chaetiger with two bilimbate chaetae with whip-like extensions, two forked chaetae and two bilimbate chaeta in each bundle. The second chaetiger with three bilimbate and two forked chaetae and all following ones with two bilimbate and two forked.

Habitat. Specimens predominantly occur at beaches with mediumsized sand grains at or above the high-water line., especially at beaches with low tidal exposure.

Distribution. The distribution is in the North-western Atlantic (US and Canadian coast) (Supplementary Fig. 1).

Etymology. The species name honours the polychaete biologist and invertebrate specialist Wilfried Westheide for his numerous contributions to systematics of interstitial polychaetes, the cryptic species problem and invertebrate systematics, and also for his mentorship.

\section{Acknowledgments}

JC is grateful to Gustav Paulay, Claudia E. Mills, Bernadette Holthuis and Tim Miller for field site suggestions in the USA. JC is 
thankful to Tim Worsfold, Andy Mackie, Henning Reiss, Lis Jørgensen for laboratory space in the UK and Norway. JC and THS are grateful to Vasily Radashevsky for hosting us in Russia, and to Nataliya Budaeva for support in obtaining Russian VISAs and funding. JC was partly funded by the Ragen Award from Friday Harbor Laboratories, and Den Grevelige Hjelmstjerne-Rosencroneske Stiftelse ved UiOslo. Funding from FORBIO - Research school in biosystematics (JC) was seminal to obtain photographs as part of a visit to Osnabrück. Funding from the ASSEMBLE project, an EU FP7 research infrastructure initiative, funded the collecting trip to Scotland (THS). JC and THS were partly supported by the SIU-funded MEDUSA project (Multidisciplinary EDUcation and reSearch in mArine biology in Norway and Russia). We acknowledge the use of the Norwegian national e-infrastructure for high-performance computing and storage via the projects NN9408K and NS9408K, respectively. The authors would like to thank two anonymous reviewers for their comments, which have substantially improved a previous version of this manuscript. This is NHM Evolutionary Genomics lab contribution nr 15.

\section{Appendix A. Supplementary material}

Supplementary data to this article can be found online at https:// doi.org/10.1016/j.ympev.2019.106663.

\section{References}

Appeltans, W., Ahyong, S.T., Anderson, G., Angel, M.V., Artois, T., Bailly, N., Bamber, R., Barber, A., Bartsch, I., Berta, A., Błazewicz-Paszkowycz, M., Bock, P., Boxshall, G., Boyko, C.B., Brandão, S.N., Bray, R.A., Bruce, N.L., Cairns, S.D., Chan, T.Y., Cheng, L., Collins, A.G., Cribb, T., Curini-Galletti, M., Dahdouh-Guebas, F., Davie, P.J.F., Dawson, M.N., De Clerck, O., Decock, W., De Grave, S., De Voogd, N.J., Domning, D.P., Emig, C.C., Erséus, C., Eschmeyer, W., Fauchald, K., Fautin, D.G., Feist, S.W., Fransen, C.H.J.M., Furuya, H., Garcia-Alvarez, O., Gerken, S., Gibson, D., Gittenberger, A., Gofas, S., Gómez-Daglio, L., Gordon, D.P., Guiry, M.D., Hernandez, F., Hoeksema, B.W., Hopcroft, R.R., Jaume, D., Kirk, P., Koedam, N., Koenemann, S., Kolb, J.B., Kristensen, R.M., Kroh, A., Lambert, G., Lazarus, D.B., Lemaitre, R, Longshaw, M., Lowry, J., MacPherson, E., Madin, L.P., Mah, C., Mapstone, G., McLaughlin, P.A., Mees, J., Meland, K., Messing, C.G., Mills, C.E., Molodtsova, T.N., Mooi, R., Neuhaus, B., Ng, P.K.L., Nielsen, C., Norenburg, J., Opresko, D.M., Osawa, M., Paulay, G., Perrin, W., Pilger, J.F., Poore, G.C.B., Pugh, P., Read, G.B., Reimer, J.D., Rius, M., Rocha, R.M., Saiz-Salinas, J.I., Scarabino, V., Schierwater, B., SchmidtRhaesa, A., Schnabel, K.E., Schotte, M., Schuchert, P., Schwabe, E., Segers, H., SelfSullivan, C., Shenkar, N., Siegel, V., Sterrer, W., Stöhr, S., Swalla, B., Tasker, M.L. Thuesen, E.V., Timm, T., Todaro, M.A., Turon, X., Tyler, S., Uetz, P., Van Der Land, J., Vanhoorne, B., Van Ofwegen, L.P., Van Soest, R.W.M., Vanaverbeke, J., Walker-

Smith, G., Walter, T.C., Warren, A., Williams, G.C., Wilson, S.P., Costello, M.J., 2012. The magnitude of global marine species diversity. Curr. Biol. 22, 2189-2202. https:// doi.org/10.1016/j.cub.2012.09.036.

Astrin, J.J., Stüben, P.E., 2008. Phylogeny in cryptic weevils: Molecules, morphology and new genera of western Palaearctic Cryptorhynchinae (Coleoptera: Curculionidae). Invertebr. Syst. 22, 503-522. https://doi.org/10.1071/IS07057.

Barnes, D.K.A., 2002. Invasions by marine life on plastic debris. Nature 416, 808-809. https://doi.org/10.1038/416808a.

Bernardo, J., 2011. A critical appraisal of the meaning and diagnosability of cryptic evolutionary diversity, and its implications for conservation in the face of climate change. Clim. Chang. Ecol. Syst. 380-438. https://doi.org/10.1017/ CBO9780511974540.019.

Bickford, D., Lohman, D.J., Sodhi, N.S., Ng, P.K.L., Meier, R., Winker, K., Ingram, K.K., Das, I., 2007. Cryptic species as a window on diversity and conservation. Trends Ecol. Evol. 22, 148-155. https://doi.org/10.1016/j.tree.2006.11.004.

Bouckaert, R., Heled, J., Kühnert, D., Vaughan, T., Wu, C.H., Xie, D., Suchard, M.A., Rambaut, A., Drummond, A.J., 2014. BEAST 2: A software platform for bayesian evolutionary analysis. PLoS Comput. Biol. 10, 1-6. https://doi.org/10.1371/journal. pcbi.1003537.

Carstens, B.C., Pelletier, T.A., Reid, N.M., Satler, J.D., 2013. How to fail at species delimitation. Mol. Ecol. 22, 4369-4383. https://doi.org/10.1111/mec.12413.

Cerca, J., Purschke, G., Struck, T.H., 2018. Marine connectivity dynamics: clarifying cosmopolitan distributions of marine interstitial invertebrates and the meiofauna paradox. Mar. Biol. 165, 123. https://doi.org/10.1007/s00227-018-3383-2.

Chernomor, O., Von Haeseler, A., Minh, B.Q., 2016. Terrace aware data structure for phylogenomic inference from supermatrices. Syst. Biol. 65, 997-1008. https://doi. org/10.1093/sysbio/syw037.

Clement, M., Posada, D., Crandall, K.A., 2000. TCS: a computer program to estimate gene genealogies. Mol. Ecol. 9, 1657-1660. https://doi.org/10.1046/j.1365-294x.2000. 01020.x.

Costa, F.O., Carvalho, G.R., 2010. New insights into molecular evolution: Prospects from the barcode of life initiative (BOLI). Theory Biosci. 129, 149-157. https://doi.org/10. 1007/s12064-010-0091-y.
Derycke, S., Remerie, T., Backeljau, T., Vierstraete, A., Vanfleteren, J., Vincx, M., Moens, T., 2008. Phylogeography of the Rhabditis (Pellioditis) marina species complex: Evidence for long-distance dispersal, and for range expansions and restricted gene flow in the northeast Atlantic. Mol. Ecol. 17, 3306-3322. https://doi.org/10.1111/j. 1365-294X.2008.03846.x.

Eldredge, N., Gould, S.J., 1972. Punctuated equilibria: An alternative to phylogetic gradualism. In: Schopf, T.J.M. (Ed.), Models in Paleobiology. Freeman, Cooper and Co., San Francisco., pp. 82-115.

Fišer, C., Robinson, C.T., Malard, F., 2018. Cryptic species as a window into the paradigm shift of the species concept. Mol. Ecol. 27, 613-635. https://doi.org/10.1111/mec. 14486.

Fujisawa, T., Barraclough, T.G., 2013. Delimiting species using single-locus data and the generalized mixed yule coalescent approach: A revised method and evaluation on simulated data sets. Syst. Biol. 62, 707-724. https://doi.org/10.1093/sysbio/syt033.

Futuyma, D.J., 2010. Evolutionary constraint and ecological consequences. Evolution (N. Y) $64,1865-1884$. https://doi.org/10.1111/j.1558-5646.2010.00960.x.

Giere, O., 2009. Meiobenthology: The Microscopic Motile Fauna of Aquatic Sediments, second ed. Springler-Verlag, Berlin Heidelberg https://doi.org/10.1016/0022 0981(94)90135-X.

Harrell Jr, F.E., Many Others, contributions from, 2019. Hmisc: Harrell Miscellaneous. R package.

Hawksworth, D.L., Lücking, R., 2017. Fungal diversity revisited: 2.2 to 3.8 million species. Microbiol. Spetrum 5, 1-17. https://doi.org/10.1128/microbiolspec.FUNK0052-2016. Correspondence.

Hellberg, M.E., 2009. Gene flow and isolation among populations of marine animals. Annu. Rev. Ecol. Evol. Syst. 40, 291-310. https://doi.org/10.1146/annurev.ecolsys. 110308.120223.

Hillis, D.M., Dixon, M.T., 1991. Ribosomal DNA: Molecular evolution and phylogenetic inference. Q. Rev. Biol. 66, 411-453.

Hoang, D.T., Chernomor, O., von Haeseler, A., Quang Minh, B., Sy Vinh, L., 2017. Ufboot2: Improving the ultrafast bootstrap approximation 35, 518-522. https://doi. org/10.5281/zenodo.854445.

Holt, B.G., Lessard, J.-P., Borregaard, M.K., Fritz, S.A., Araújo, M.B., Dimitrov, D., Fabre, P.-H., Graham, C.H., Graves, G.R., Jønsson, K.A., Nogués-Bravo, D., Wang, Z. Whittaker, R.J., Fjeldså, J., Rahbek, C., 2013. An update of Wallace's zoogeographic regions of the world. Science (80-.) 339, 74-79. https://doi.org/10.1590/S141381232011000600020.

Horton, T., et al., 2019. World Register of Marine Species, taxon details for Orbiniidae Hartman, 1942 [WWW Document]. http://www.marinespecies.org/aphia.php?p= taxdetails\&id $=902 \&$ allchildren $=1$.

Johannesson, K., 1988. The paradox of Rockall: why is a brooding gastropod (Littorina saxatilis) more widespread than one having a planktonic larval dispersal stage ( $L$. littorea)? Mar. Biol. 99, 507-513. https://doi.org/10.1007/BF00392558.

Jörger, K.M., Norenburg, J.L., Wilson, N.G., Schrödl, M., 2012. Barcoding against a paradox? Combined molecular species delineations reveal multiple cryptic lineages in elusive meiofaunal sea slugs. BMC Evol. Biol. 12, 245. https://doi.org/10.1186/ 1471-2148-12-245.

Jörger, K.M., Schrödl, M., 2013. How to describe a cryptic species? Practical challenges of molecular taxonomy. Front. Zool. 10, 59. https://doi.org/10.1186/1742-9994-10-59.

Kalyaanamoorthy, S., Minh, B.Q., Wong, T.K.F., Von Haeseler, A., Jermiin, L.S., 2017. ModelFinder: Fast model selection for accurate phylogenetic estimates. Nat. Methods 14, 587-589. https://doi.org/10.1038/nmeth.4285.

Karling, T.G., 1958. Zur Kenntnis von Stygocapitella subterranea Knöllner und Parergodrilus heideri Reisinger. Ark. för Zool. 1, 307-324.

Katoh, K., Standley, D.M., 2013. MAFFT multiple sequence alignment software version 7: Improvements in performance and usability. Mol. Biol. Evol. 30, 772-780. https:// doi.org/10.1093/molbev/mst010.

Knöllner, F., 1934. Stypocapitella subterranea nov.gen. nov.spec. Schriften der Naturwissenschaftlichen Vereins für Schleswig-Holstein 20, 468-472.

Knowlton, N., 2000. Molecular genetic analyses of species boundaries in the sea. Hydrobiologia 420, 73-90. https://doi.org/10.1023/A:1003933603879.

Knowlton, N., 1993. Sibling species in the sea. Annu. Rev. Ecol. Syst. 24, 189-216.

Kon, T., Yoshino, T., Mukai, T., Nishida, M., 2007. DNA sequences identify numerous cryptic species of the vertebrate: A lesson from the gobioid fish Schindleria. Mol. Phylogenet. Evol. 44, 53-62. https://doi.org/10.1016/j.ympev.2006.12.007.

Korshunova, T., Martynov, A., Bakken, T., Picton, B., 2017. External diversity is restrained by internal conservatism: New nudibranch mollusc contributes to the cryptic species problem. Zool. Scr. 46, 683-692. https://doi.org/10.1111/zsc.12253.

Korshunova, T., Picton, B., Furfaro, G., Mariottini, P., Pontes, M., Prkić, J., Fletcher, K., Malmberg, K., Lundin, K., Martynov, A., 2019. Multilevel fine-scale diversity challenges the 'cryptic species' concept. Sci. Rep. 9, 6732. https://doi.org/10.1038/ s41598-019-42297-5.

Kück, P., Meusemann, K., 2010. FASconCAT: Convenient handling of data matrices. Mol. Phylogenet. Evol. 56, 1115-1118. https://doi.org/10.1016/j.ympev.2010.04.024.

Leasi, F., Norenburg, J.L., 2016. At least some meiofaunal species are not everywhere Indication of geographic, ecological and geological barriers affecting the dispersion of species of Ototyphlonemertes (Nemertea, Hoplonemertea). Mol. Ecol. 25, 1381-1397. https://doi.org/10.1111/mec.13568.

Leasi, F., Norenburg, J.L., 2014. The necessity of DNA taxonomy to reveal cryptic diversity and spatial distribution of meiofauna, with a focus on Nemertea. PLoS ONE 9. https://doi.org/10.1371/journal.pone.0104385.

Lee, C.E., Frost, B.W., 2002. Morphological stasis in the Eurytemora affinis species complex (Copepoda: Temoridae). Hydrobiologia 480, 111-128. https://doi.org/10.1023/ A:1021293203512.

Lehmacher, C., Ramey-balci, P.A., Wolff, L.I., Fiege, D., 2016. Ultrastructural differences in presumed photoreceptive organs and molecular data as a means for species 
discrimination in Polygordius (Annelida, Protodriliformia, Polygordiidae). Org. Divers. Evol. https://doi.org/10.1007/s13127-016-0272-8.

Lenth, R.V., 2013. Lsmeans: Least-squares means. R package version 1.10-4. http:// CRAN.R-project.org/package = lsmeans [WWW Document].

Leray, M., Knowlton, N., 2016. Censusing marine eukaryotic diversity in the twenty-first century. Philos. Trans. R. Soc. B Biol. Sci. 371, 20150331.

Lobo, J., Teixeira, M.A.L., Borges, L.M.S., Ferreira, M.S.G., Hollatz, C., Gomes, P.T., Sousa, R., Ravara, A., Costa, M.H., Costa, F.O., 2016. Starting a DNA barcode reference library for shallow water polychaetes from the southern European Atlantic coast. Mol. Ecol. Resour. 16, 298-313. https://doi.org/10.1111/1755-0998.12441.

Mack, R.N., Lonsdale, W.M., 2001. Humans as global plant dispersers: getting more than we bargained for. Bioscience 51, 95. https://doi.org/10.1641/0006-3568(2001) 051 [0095:hagpdg]2.0.co;2.

Meyer-Wachsmuth, I., Curini Galletti, M., Jondelius, U., 2014. Hyper-cryptic marine meiofauna: Species complexes in Nemertodermatida. PLoS ONE 9. https://doi.org/ 10.1371/journal.pone.0107688.

Múrias Dos Santos, A., Cabezas, M.P., Tavares, A.I., Xavier, R., Branco, M., 2015. TcsBU: A tool to extend TCS network layout and visualization. Bioinformatics 32, 627-628. https://doi.org/10.1093/bioinformatics/btv636.

Nguyen, L.T., Schmidt, H.A., Von Haeseler, A., Minh, B.Q., 2015. IQ-TREE: A fast and effective stochastic algorithm for estimating maximum-likelihood phylogenies. Mol. Biol. Evol. 32, 268-274. https://doi.org/10.1093/molbev/msu300.

Nygren, A., Parapar, J., Pons, J., Meißner, K., Bakken, T., Kongsrud, J.A., Oug, E., Gaeva, D., Sikorski, A., Johansen, R.A., Hutchings, P.A., Lavesque, N., Capa, M., 2018. A mega-cryptic species complex hidden among one of the most common annelids in the north east Atlantic. PLoS ONE. https://doi.org/10.1371/journal.pone.0198356.

Nygren, A., Pleijel, F., 2011. From one to ten in a single stroke - resolving the European Eumida sanguinea (Phyllodocidae, Annelida) species complex. Mol. Phylogenet. Evol. 58, 132-141. https://doi.org/10.1016/j.ympev.2010.10.010.

Palumbi, S., Martin, A., Romano, S., McMillan, W.O., Stice, L., Grabowski, G., 1991. The simple fool's guide to PCR, version 2.

Pante, E., Puillandre, N., Viricel, A., Arnaud-Haond, S., Aurelle, D., Castelin, M., Chenuil, A., Destombe, C., Forcioli, D., Valero, M., Viard, F., Samadi, S., 2015. Species are hypotheses: avoid connectivity assessments based on pillars of sand. Mol. Ecol. 24, 525-544. https://doi.org/10.1111/mec.13048.

Purschke, G., 2006. Problematic Annelid Groups. In: Rouse, G.W., Pleijel, F. (Eds.), Reproductive Biology and Phylogeny of Annelida. Science Publisher, Enfield, Jersey, Plymouth, pp. 639-667.

Purschke, G., 1999. Terrestrial polychaetes - Models for the evolution of the Clitellata (Annelida)? Hydrobiologia 406, 87-99. https://doi.org/10.1023/A:1003780032497.

Purschke, G., 1987. Anatomy and ultrastructure of ventral pharyngeal organs and their phylogenetic importance in Polychaeta (Annelida) - III. The pharynx of the Parergodrilidae. Zool. Jahrbücher Anat. 115, 331-362.

Purschke, G., 1986. Ultrastructure of the nuchal organ in the interstitial polychaete Stygocapitella subterranea (Parergodriilidae). Zool. Scr. 15, 13-20.

Purschke, G., Böggemann, M., Westheide, W., 2019. Parergodrilidae reisinger. 1925 In: Purschke, G., Böggemann, M., Westheide, W. (Eds.), Annelida, Volume 1: Annelida Basal Groups and Pleistoannelida, Sedentaria. De Gruyter, Berlin, Boston, pp. 237-250.

Purschke, G., Fursman, M.C., 2005. Spermatogenesis and Spermatozoa in Stygocapitella subterranea (Annelida, Parergodrilidae), an Enigmatic Supralittoral Polychaete. Zoomorphology 124, 137-148. https://doi.org/10.1007/s00435-005-0001-x.

Purschke, G., Jördens, J., 2007. Male genital organs in the eulittoral meiofaunal polychaete stygocapitella subterranea (Annelida, Parergodrilidae): Ultrastructure, functional and phylogenetic significance. Zoomorphology 126, 283-297. https://doi.org/ 10.1007/s00435-007-0047-z

R Core Team, 2013. R: A language and environment for statistical computing. R Foundation for Statistical Computing, Vienna, Austria. URL http://www.R-project. org/. [WWW Document].

Radziejewska, T., Gruszka, P., Rokicka-Praxmajer, J., 2006. A home away from home: A meiobenthic assemblage in a ship's ballast water tank sediment. Oceanologia 48 , 259-265.

Rambaut, A., Drummond, A.J., Suchard, M.A., 2007. Tracer v1.6.

Riser, N.W., 1984. General observations on the intertidal interstitial fauna of New Zealand. Tane 30, 239-250.

Riser, N.W., 1980. The aberrant polychaete Stygocapitella from some American beaches. Wasmann J. Biol. 38, 10-17.

Schmidt, H., Westheide, W., 2000. Are the meiofaunal polychaetes Hesionides arenaria and Stygocapitella subterranea true cosmopolitan species? - results of RAPD-PCR investigations. Zool. Scr. 29, 17-27. https://doi.org/10.1046/j.1463-6409.2000. 00026.x.

Schmidt, P., 1972a. Zonierung und jahreszeitliche Fluktuationen des Mesopsammons im Sandstrand von Schilksee. Mikrofauna des Meeresbodens 10, 1-60.
Schmidt, P., 1972b. Zonierung und jahreszeitliche Fluktuationen des Mesopsammons im Sandstrand von Schilksee (Kieler Bucht). Mikrofauna des Meeresbodens 10, 1-60.

Schmidt, P., 1970. Zonation of the interstitial polychaete Stygocapitella subterranea (Stygocapitellidae) in European sandy beaches. Mar. Biol. 7, 319-323.

Schmidt, P., 1969. Die quantitative Verteilung und Populationdynamik des Mesopsammons am Gezeiten-Sandstrand der Nordseeinsel Sylt - II. Quantitative verteilung und populationsdynamik einzelner Arten. Int. Rev. der gesamten Hydrobiol. und Hydrogr. 54, 95-174.

Schonrogge, K., Barr, B., Wardlaw, J., Napper, E., Gardner, M., Breen, J., Elmes, G. Thomas, J.A., 2002. When rare species become endangered: Cryptic speciation in myrmecolphilous hoverflies. J. Linn. Soc. 75, 291-300. https://doi.org/10.1046/j. 1095-8312.2002.00019.x.

Singhal, S., Hoskin, C.J., Couper, P., Potter, S., Moritz, C., 2018. A framework for resolving cryptic species: a case study from the lizards of the Australian Wet Tropics. Syst. Biol. https://doi.org/10.1093/sysbio/syy026/4960881.

Sterrer, W., 1973. Plate tectonics as a mechanism for dispersal and speciation in interstitial sand fauna. Netherlands J. Sea Res. 7, 200-222.

Struck, T.H., Cerca, J., 2019. Cryptic species and their Evolutionary significance. eLS 1-9. https://doi.org/10.1002/9780470015902.a0028292.

Struck, T.H., Feder, J.L., Bendiksby, M., Birkeland, S., Cerca, J., Gusarov, V.I., Kistenich, S., Larsson, K.-H.H., Liow, L.H., Nowak, M.D., Stedje, B., Bachmann, L., Dimitrov, D., 2018a. Finding evolutionary processes hidden in cryptic species. Trends Ecol. Evol. 1-11. https://doi.org/10.1016/j.tree.2017.11.007.

Struck, T.H., Feder, J.L., Bendiksby, M., Birkeland, S., Cerca, J., Gusarov, V.I., Kistenich, S., Larsson, K.-H.H., Liow, L.H., Nowak, M.D., Stedje, B., Bachmann, L., Dimitrov, D., 2018b. Cryptic species - more than terminological chaos: a reply to heethoff. Trends Ecol. Evol. 33, 310-312. https://doi.org/10.1016/j.tree.2018.02.008.

Struck, T.H., Koczula, J., Stateczny, D., Meyer, C., Purschke, G., 2017. Two new species in the annelid genus Stygocapitella (Orbiniida, Parergodrilidae) with comments on their biogeography. Zootaxa 4286, 301-332. https://doi.org/10.11646/zootaxa.4286.3.1.

Struck, T.H., Westheide, W., Purschke, G., 2002. Progenesis in Eunicida ("Polychaeta", Annelida) - Separate evolutionary events? Evidence from molecular data. Mol. Phylogenet. Evol. 25, 190-199. https://doi.org/10.1016/S1055-7903(02)00231-2.

Suatoni, E., Vicario, S., Rice, S., Snell, T., Caccone, A., 2006. An analysis of species boundaries and biogeographic patterns in a cryptic species complex: The rotifer-Brachionus plicatilis. Mol. Phylogenet. Evol. 41, 86-98. https://doi.org/10. 1016/j.ympev.2006.04.025.

Swift, H.F., Daglio, L.G., Dawson, M.N., 2016. Three routes to crypsis: stasis, convergence, and parallelism in the Mastigias species complex (Scyphozoa, Rhizostomeae). Mol Phylogenet. Evol. 99, 103-115. https://doi.org/10.1016/j.ympev.2016.02.013.

Wada, S., Kameda, Y., Chiba, S., 2013. Long-term stasis and short-term divergence in the phenotypes of microsnails on oceanic islands. Mol. Ecol. 22, 4801-4810. https://doi. org $/ 10.1111 /$ mec. 12427.

Weber, A.A.-T., Stöhr, S., Chenuil, A., 2019. Species delimitation in the presence of strong incomplete lineage sorting and hybridization. Mol. Phylogenet. Evol. 131, 240218. https://doi.org/10.1101/240218.

Westheide, W., 2008. Polychaetes: Interstitial families, 2nd Editio. ed. Field Studies Council, Shrewsbury, 169 pp.

Westheide, W., 1991. The meiofauna of the Galapagos: a review. In: James, Mathew J. (Ed.), Galápagos Marine Invertebrates. Springler, New York, pp. 37-69.

Westheide, W., 1990. Polychaetes: interstitial families. Keys and notes for the identification of the species., Universal. ed.

Westheide, W., 1987. Progenesis as a principle in meiofauna evolution. J. Nat. Hist. 21, 843-854. https://doi.org/10.1080/00222938700770501.

Westheide, W., 1977. The geographical distribution of interstitial polychaetes. Mikrofauna Meeresb. 61, 287-302.

Westheide, W., 1966. On the polychaete fauna of the eulitoral of the North Sea island Sylt. Zur Polychaetenfauna des Eulitorals der Nord. Sylt 13, 203-209.

Westheide, W., Purschke, G., 1988. Organism processing. In: Higgins, R.P., Thiel, H. (Eds.), Introduction to the Study of Meiofauna. Smithsonian Institution Press, Washington, pp. 146-160.

Wickham, H., 2016. ggplot2: Elegant Graphics for Data Analysis. Springer-Verlag, New York.

Worsfold, T.M., 2008. British records of the interstitial polychaete Stygocapitella subterranea (Annelida: Parergodrilidae). Mar. Biodivers. Rec. 1, 50-52. https://doi.org/ 10.1017/S1755267206004295.

Zanol, J., Halanych, K.M., Struck, T.H., Fauchald, K., 2010. Phylogeny of the bristle worm family Eunicidae (Eunicida, Annelida) and the phylogenetic utility of noncongruent 16S, COI and 18S in combined analyses. Mol. Phylogenet. Evol. 55, 660-676. https:// doi.org/10.1016/j.ympev.2009.12.024

Zhang, J., Kapli, P., Pavlidis, P., Stamatakis, A., 2013. A general species delimitation method with applications to phylogenetic placements. Bioinformatics 29 , 2869-2876. https://doi.org/10.1093/bioinformatics/btt499. 